\title{
LEVEL II SCOUR ANALYSIS FOR BRIDGE 34 (HUNTTH00210034) on TOWN HIGHWAY 21, crossing BRUSH BROOK, HUNTINGTON, VERMONT
}

\section{Open-File Report 97-663}

Prepared in cooperation with

VERMONT AGENCY OF TRANSPORTATION

and

FEDERAL HIGHWAY ADMINISTRATION

U.S. Department of the Interior

U.S. Geological Survey

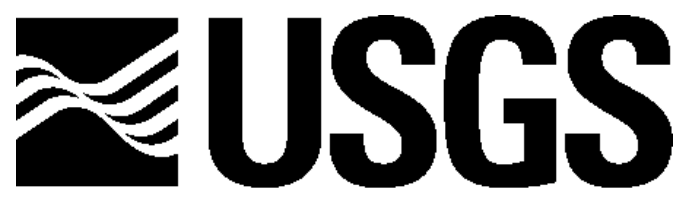




\section{LEVEL II SCOUR ANALYSIS FOR BRIDGE 34 (HUNTTH00210034) on TOWN HIGHWAY 21, crossing BRUSH BROOK, HUNTINGTON, VERMONT}

By RONDA L. BURNS \& MICHAEL A. IVANOFF

U.S. Geological Survey Open-File Report 97-663

Prepared in cooperation with

VERMONT AGENCY OF TRANSPORTATION and

FEDERAL HIGHWAY ADMINISTRATION 


\title{
U.S. DEPARTMENT OF THE INTERIOR BRUCE BABBITT, Secretary
}

\author{
U.S. GEOLOGICAL SURVEY \\ Mark Schaefer, Acting Director
}

For additional information write to:

District Chief

U.S. Geological Survey 361 Commerce Way

Pembroke, NH 03275-3718
Copies of this report may be purchased from:

U.S. Geological Survey

Branch of Information Services

Open-File Reports Unit

Box 25286

Denver, CO 80225-0286 


\section{CONTENTS}

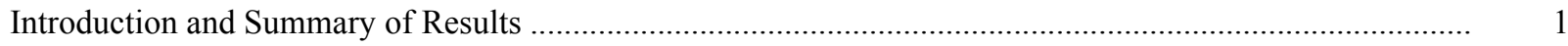

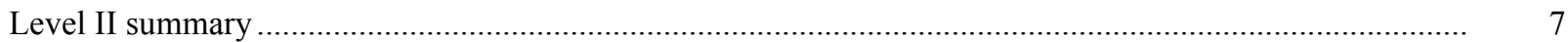

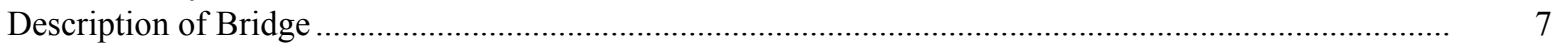

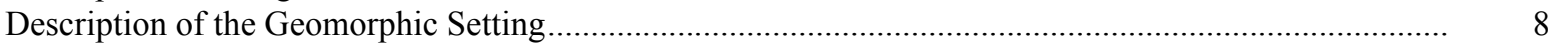

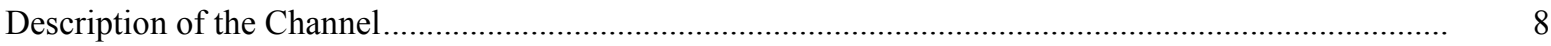

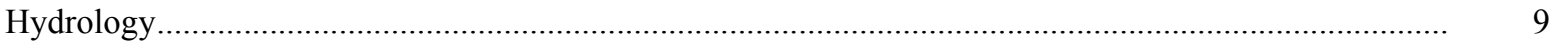

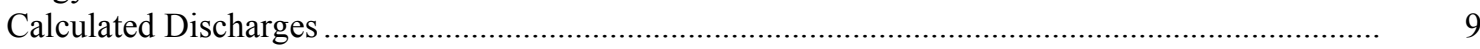

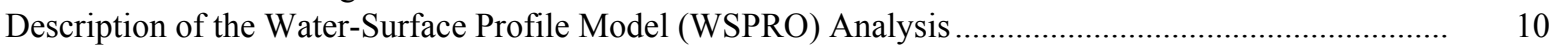

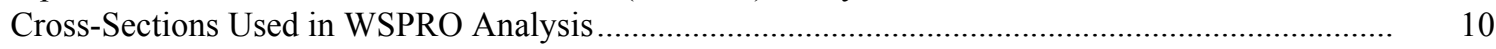

Data and Assumptions Used in WSPRO Model ..................................................................... 11

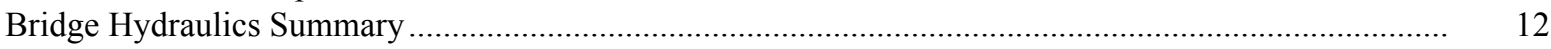

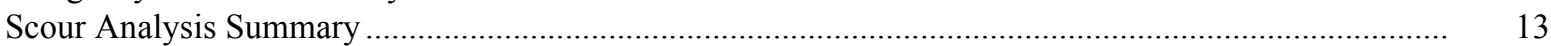

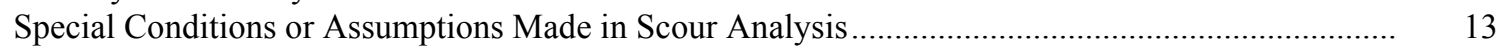

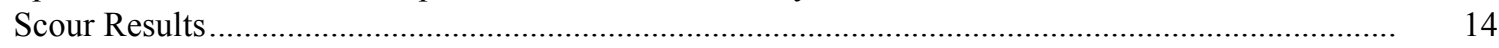

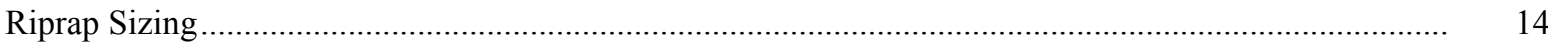

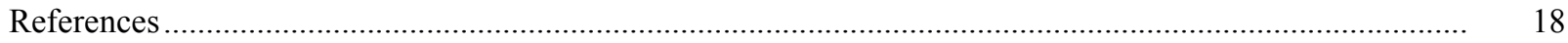

Appendixes:

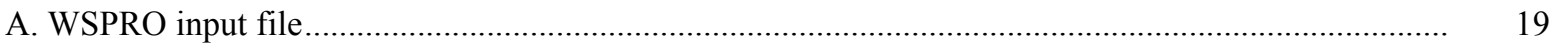

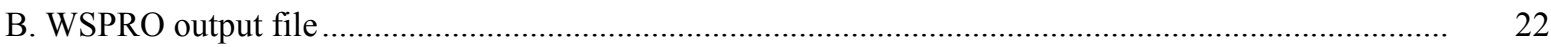

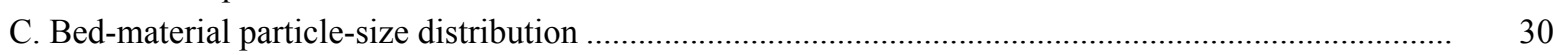

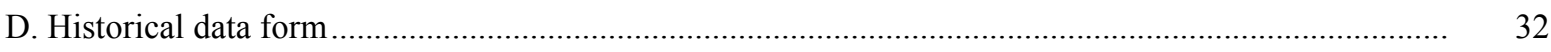

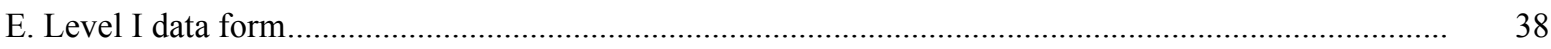

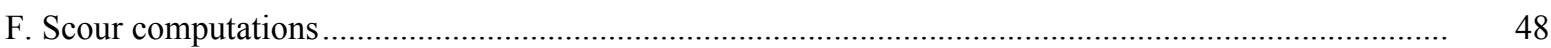

\section{FIGURES}

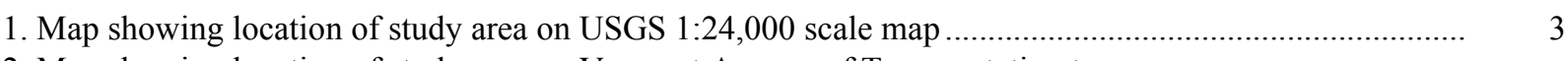

2. Map showing location of study area on Vermont Agency of Transportation town
highway map

3. Structure HUNTTH00210034 viewed from upstream (June 26, 1996) ..................................................

4. Downstream channel viewed from structure HUNTTH00210034 (June 26, 1996)............................. 5

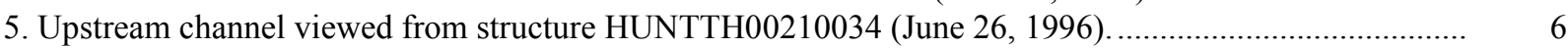

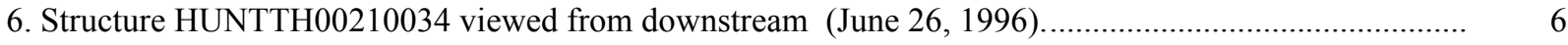

7. Water-surface profiles for the 100- and 500-year discharges at structure

HUNTTH00210034 on Town Highway 21, crossing Brush Brook,

Huntington, Vermont.

8. Scour elevations for the 100- and 500-year discharges at structure

HUNTTH00210034 on Town Highway 21, crossing Brush Brook,

Huntington, Vermont.

\section{TABLES}

1. Remaining footing/pile depth at abutments for the 100-year discharge at structure

HUNTTH00210034 on Town Highway 21, crossing Brush Brook,

Huntington, Vermont....

2. Remaining footing/pile depth at abutments for the 500-year discharge at structure

HUNTTH00210034 on Town Highway 21, crossing Brush Brook,

Huntington, Vermont. 


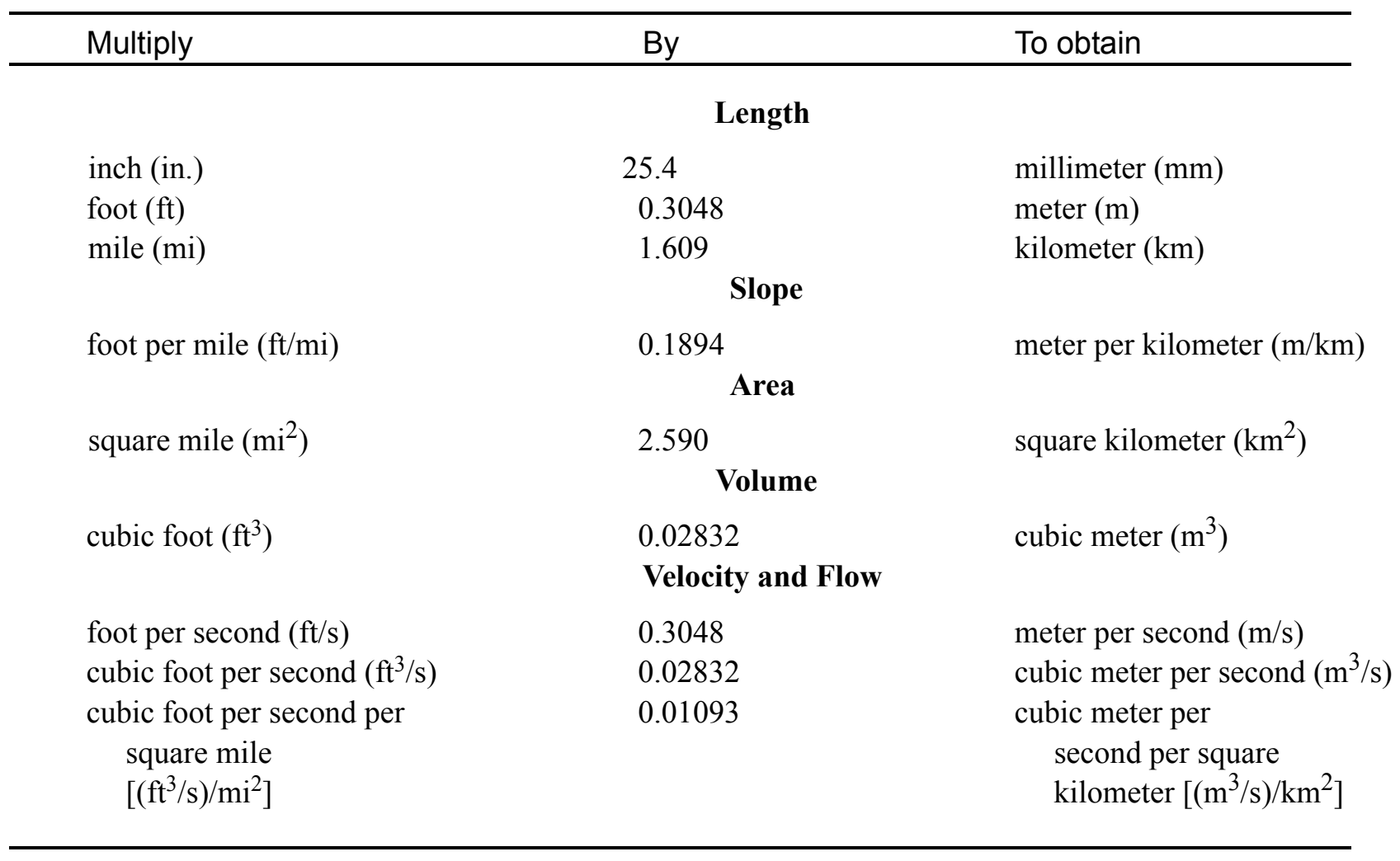

\section{OTHER ABBREVIATIONS}

$\begin{array}{lrlr}\mathrm{BF} & \text { bank full } & \text { LWW } & \text { left wingwall } \\ \mathrm{cfs} & \text { cubic feet per second } & \text { MC } & \text { main channel } \\ \mathrm{D}_{50} & \text { median diameter of bed material } & \text { RAB } & \text { right abutment } \\ \mathrm{DS} & \text { downstream } & \text { RABUT } & \text { face of right abutment } \\ \mathrm{elev} & \text { elevation } & \text { RB } & \text { right bank } \\ \mathrm{f} / \mathrm{p} & \text { flood plain } & \text { ROB } & \text { right overbank } \\ \mathrm{ft}^{2} & \text { square feet } & \text { RWW } & \text { right wingwall } \\ \mathrm{ft} / \mathrm{ft} & \text { feet per foot } & \text { TH } & \text { town highway } \\ \mathrm{JCT} & \text { junction } & \text { UB } & \text { under bridge } \\ \mathrm{LAB} & \text { left abutment } & \text { US } & \text { upstream } \\ \mathrm{LABUT} & \text { face of left abutment } & \text { USGS } & \text { United States Geological Survey } \\ \mathrm{LB} & \text { left bank } & \text { VTAOT Vermont Agency of Transportation } \\ \mathrm{LOB} & \text { left overbank } & \text { WSPRO } & \text { water-surface profile model }\end{array}$

In this report, the words "right" and "left" refer to directions that would be reported by an observer facing downstream. Sea level: In this report, "sea level" refers to the National Geodetic Vertical Datum of 1929-- a geodetic datum derived from a general adjustment of the first-order level nets of the United States and Canada, formerly called Sea Level Datum of 1929.

In the appendices, the above abbreviations may be combined. For example, USLB would represent upstream left bank. 


\title{
LEVEL II SCOUR ANALYSIS FOR BRIDGE 34 (HUNTTH00210034) ON TOWN HIGHWAY 21, CROSSING BRUSH BROOK, HUNTINGTON, VERMONT
}

\author{
By Ronda L. Burns and Michael A. Ivanoff
}

\section{INTRODUCTION AND SUMMARY OF RESULTS}

This report provides the results of a detailed Level II analysis of scour potential at structure HUNTTH00210034 on Town Highway 21 crossing Brush Brook, Huntington, Vermont (figures 1-8). A Level II study is a basic engineering analysis of the site, including a quantitative analysis of stream stability and scour (U.S. Department of Transportation, 1993). Results of a Level I scour investigation also are included in Appendix E of this report. A Level I investigation provides a qualitative geomorphic characterization of the study site. Information on the bridge, gleaned from Vermont Agency of Transportation (VTAOT) files, was compiled prior to conducting Level I and Level II analyses and is found in Appendix D.

The site is in the Green Mountain section of the New England physiographic province in central Vermont. The $6.23-\mathrm{mi}^{2}$ drainage area is in a predominantly rural and forested basin. In the vicinity of the study site, the surface cover is forest.

In the study area, Brush Brook has an incised, straight channel with a slope of approximately $0.03 \mathrm{ft} / \mathrm{ft}$, an average channel top width of $43 \mathrm{ft}$ and an average bank height of $4 \mathrm{ft}$. The channel bed material ranges from gravel to boulder with a median grain size $\left(\mathrm{D}_{50}\right)$ of $90.0 \mathrm{~mm}(0.295 \mathrm{ft})$. The geomorphic assessment at the time of the Level I and Level II site visit on June 26, 1996, indicated that the reach was stable.

The Town Highway 21 crossing of Brush Brook is a 28 -ft-long, one-lane bridge consisting of one 26-foot steel-beam span with a timber deck (Vermont Agency of Transportation, written communication November 30,1995). The opening length of the structure parallel to the bridge face is $25.4 \mathrm{ft}$. The bridge is supported by vertical, concrete abutments with a wingwall on the upstream right. The channel is skewed approximately 5 degrees to the opening and the computed opening-skew-to-roadway is 5 degrees. 
A tributary enters Brush Brook on the right bank immediately downstream of the bridge. At the confluence, the left bank of Brush Brook is eroded and there is a small void under the downstream end of the left abutment footing which is completely exposed. The right abutment footing is also exposed. The scour countermeasures at the site include type-2 stone fill (less than 36 inches diameter) along the upstream banks and in front of the right abutment and type- 3 stone fill (less than 48 inches diameter) along the entire base length of the upstream right wingwall and along the downstream right bank. Additional details describing conditions at the site are included in the Level II Summary and Appendices D and $\mathrm{E}$.

Scour depths and recommended rock rip-rap sizes were computed using the general guidelines described in Hydraulic Engineering Circular 18 (Richardson and others, 1995) for the 100- and 500-year discharges. In addition, the incipient roadway-overtopping discharge is determined and analyzed as another potential worst-case scour scenario. Total scour at a highway crossing is comprised of three components: 1) long-term streambed degradation; 2) contraction scour (due to accelerated flow caused by a reduction in flow area at a bridge) and; 3 ) local scour (caused by accelerated flow around piers and abutments). Total scour is the sum of the three components. Equations are available to compute depths for contraction and local scour and a summary of the results of these computations follows.

Contraction scour for all modelled flows ranged from 0.0 to $0.7 \mathrm{ft}$. The worst-case contraction scour occurred at the incipient roadway-overtopping discharge, which was less than the 100-year discharge. Abutment scour ranged from 6.9 to $10.9 \mathrm{ft}$. The worst-case abutment scour occurred at the 500-year discharge. Additional information on scour depths and depths to armoring are included in the section titled "Scour Results". Scouredstreambed elevations, based on the calculated scour depths, are presented in tables 1 and 2. A cross-section of the scour computed at the bridge is presented in figure 8. Scour depths were calculated assuming an infinite depth of erosive material and a homogeneous particlesize distribution.

It is generally accepted that the Froehlich equation (abutment scour) gives "excessively conservative estimates of scour depths" (Richardson and others, 1995, p. 47). Usually, computed scour depths are evaluated in combination with other information including (but not limited to) historical performance during flood events, the geomorphic stability assessment, existing scour protection measures, and the results of the hydraulic analyses. Therefore, scour depths adopted by VTAOT may differ from the computed values documented herein. 


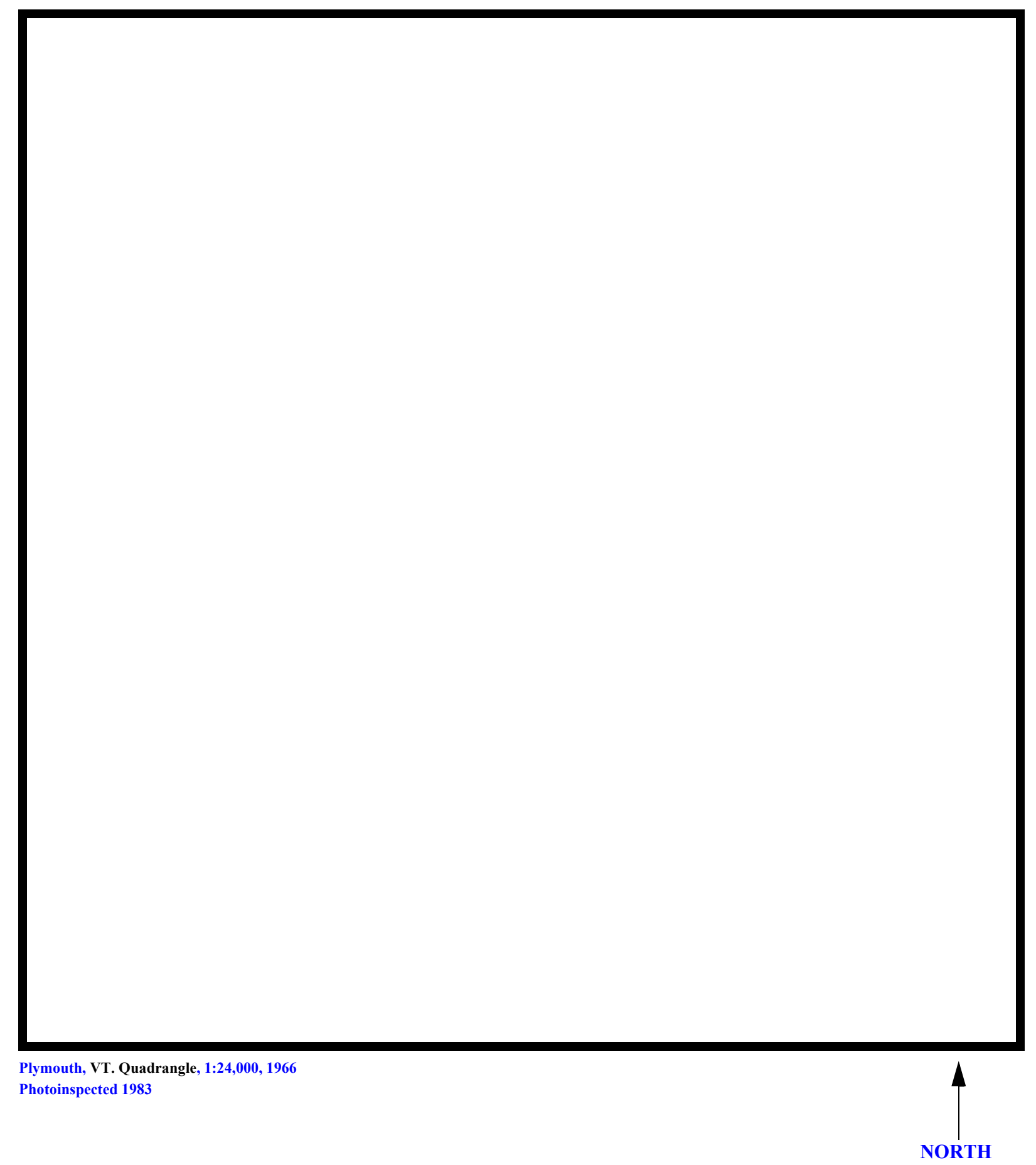

Figure 1. Location of study area on USGS 1:24,000 scale map. 
Figure 2. Location of study area on Vermont Agency of Transportation town highway map. 

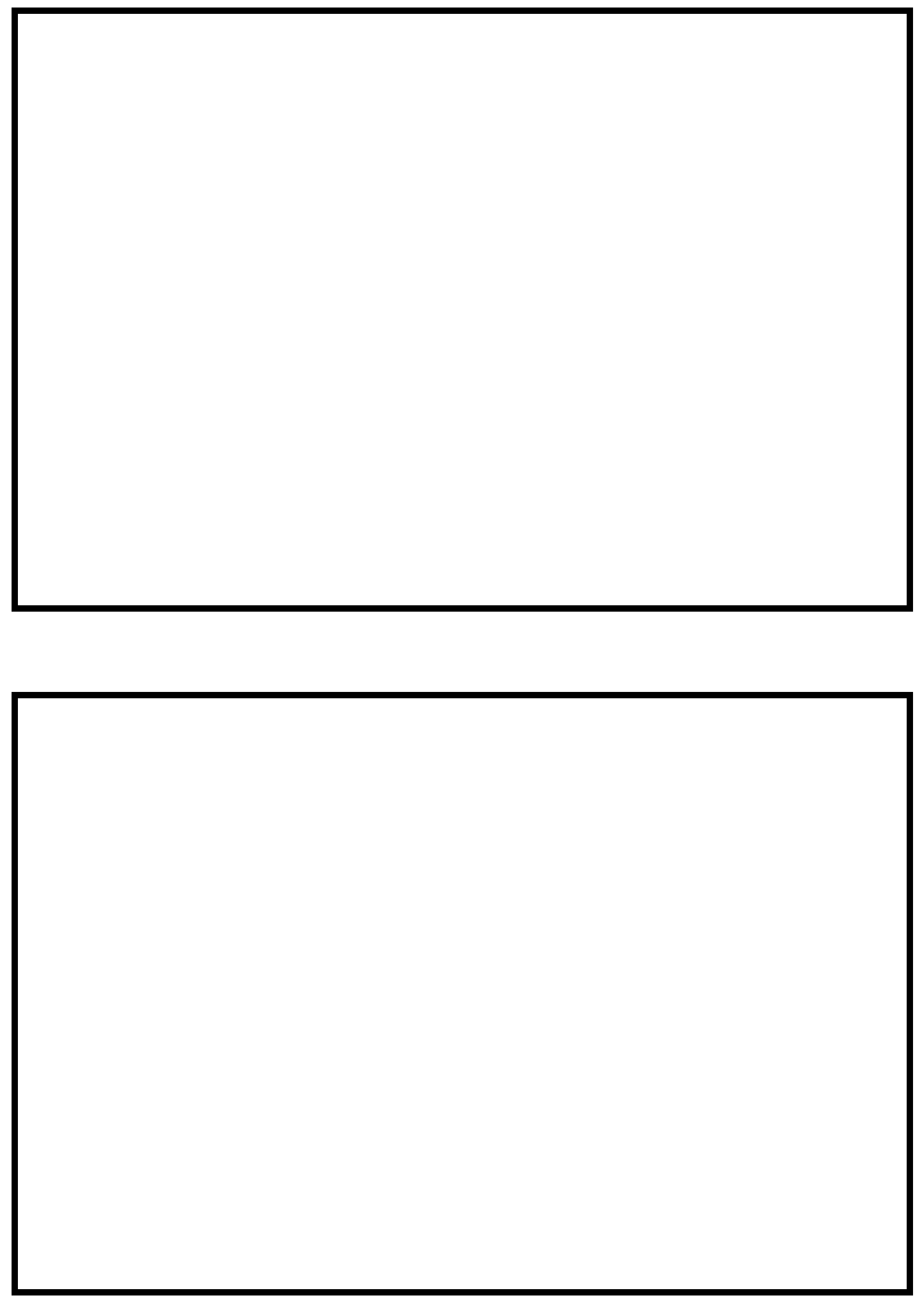

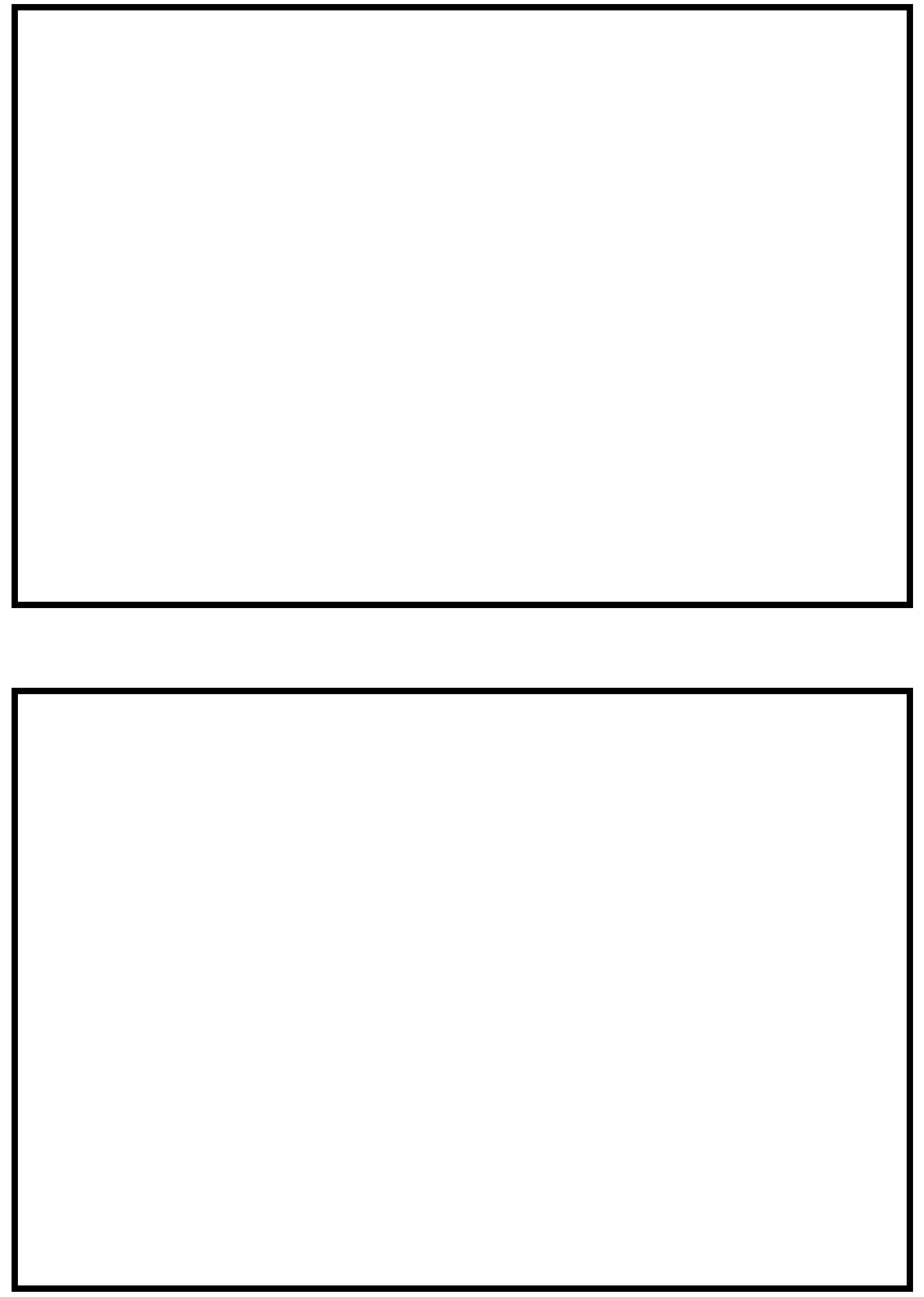


\section{LEVEL II SUMMARY}

\begin{tabular}{llllll} 
Structure Number & HUNTTH00210034 & & \multicolumn{2}{c}{ Brush Brook } \\
Stream & & & \\
County & Chittenden & Road & TH 21 & District & 5
\end{tabular}

\section{Description of Bridge}

\begin{tabular}{|c|c|c|c|}
\hline Bridge length & Bridge width & 16.1 & \multirow{2}{*}{ Max span length } \\
\hline \multicolumn{3}{|c|}{ Alignment of bridge to road (on curve or straight) } & \\
\hline $\begin{array}{r}\text { Alugnment of bridge to ro } \\
\text { Vertica }\end{array}$ & $\begin{array}{l}\text { di con curve or stral } \\
1 \text {, concrete }\end{array}$ & \multirow{2}{*}{ Embankment type } & Sloping \\
\hline Abutment type & Yes & & $06 / 26 / 96$ \\
\hline \multirow{2}{*}{$\begin{array}{l}\text { Stone fill on abutment? } \\
\text { naninti... } \\
\text { Wingwall. }\end{array}$} & Type-2, along the $\mathrm{r}$ & $\begin{array}{l}\text { Dato of incnortion } \\
\text { right abutment and ty }\end{array}$ & ype-3, along the upstream right \\
\hline & & & \\
\hline
\end{tabular}

Abutments and wingwalls are concrete. The footings

are exposed on both abutments and there is a small void under the downstream end of the left abutment.

Yes 5

Is bridge skewed to flood flow according to. Yes ' survey? Angle

There is a moderate channel bend in the downstream, reach

Debris accumulation on bridge at time of Level I or Level II site visit:

Date of insnortion $06 / 26 / 96$

Level I

$06 / 26 / 96$

\section{Percent of rhannol blocked nortzontatly}

$$
0
$$

Percent of allonel
blocked verticatty 0

Level II

Moderate. Trees along the left and right banks have exposed roots.

A tributary enters on the right bank immediately downstream of the bridge. At the Potential for debris

confluence, the left bank of Brush Brook is eroded where flow from the tributary impacts the Doscriho anv, fonturos noar ar at tho hridos that mav affort flow, (includo ohsorvation dato) bank. 06/26/96 


\section{Description of the Geomorphic Setting}

General topography The channel is located within a moderate relief valley with a steep valley wall on the right.

Geomorphic conditions at bridge site: downstream (DS), upstream (US)

Date of inspection $\quad 06 / 26 / 96$

DS left: $\quad$ Steep channel bank to a moderately sloped overbank

DS right: $\quad$ Steep channel bank to a narrow terrace and steep valley wall

US left: $\quad$ Steep channel bank to a moderately sloped overbank

US right: $\quad$ Steep channel bank to a narrow terrace and steep valley wall

\section{Description of the Channel}

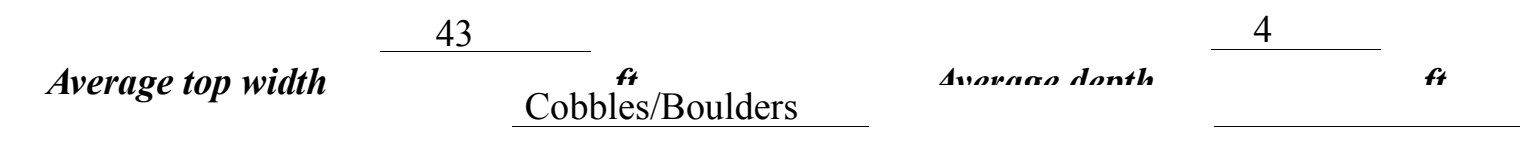

Predominant bed material

Bank material

Cobbles/Boulders

Straight and stable with semi-alluvial to non-alluvial channel boundaries.

$06 / 26 / 96$

Vegetative co 1 Trees and brush

DS left: $\quad$ Trees and brush

DS right: $\quad$ Trees and brush

US left: $\quad$ Trees and brush

US right: $\quad$ Yes

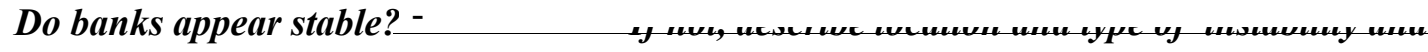

date of observatton.

None. 06/26/96

Describe any obstructions in channel and date of observation. 


\title{
Hydrology
}

Drainage area $\quad 6.23 \mathrm{mi}^{2}$

Percentage of drainage area in physiographic provinces: (approximate)

Physiographic province/section

New England/Green Mountain
Percent of drainage area 100

\begin{abstract}
Is drainage area considered rural or urban?
Rural urbanization:

Describe any significant
\end{abstract}

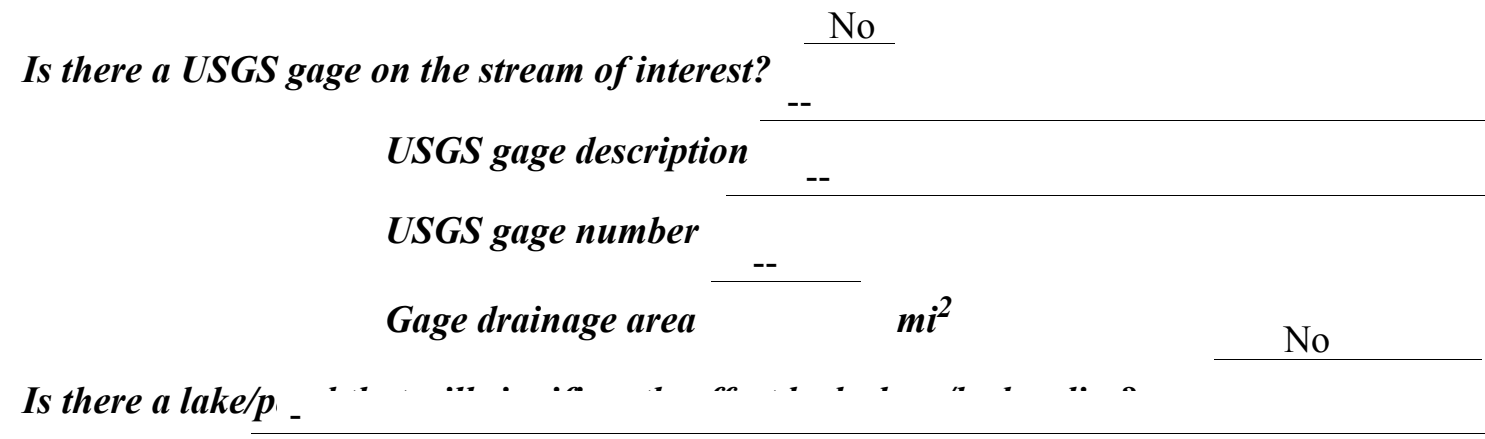

$0100 \quad 0500 \quad f t^{3} / \mathrm{s} / \mathrm{s}$

The discharges are interpolated between flood

frequency estimates for drainage aregas of 9.19 square miles and 5.01 square miles available from the VTAOT database (Vermont Agency of Transportation, written communication, May, 1995) and graphically extrapolated to the 500-year event. The values used were within a range defined by flood frequency curves developed from several empirical methods (Benson, 1962; Johnson and Tasker, 1974; FHWA, 1983; Potter, 1957a\&b; Talbot, 1887). 


\section{Description of the Water-Surface Profile Model (WSPRO) Analysis}

Datum for WSPRO analysis (USGS survey, sea level, VTAOT plans)

USGS survey

Datum tie between USGS survey and VTAOT plans

Add 328.0 to the USGS arbitrary

survey datum to obtain VTAOT plans' datum.

Description of reference marks used to determine USGS datum. $\quad$ RM1 is a metal tablet

stamped "State of Vermont survey mark" on top of the downstream end of the right abutment of

HUNTTH00220033 (elev. $497.14 \mathrm{ft}$, arbitrary survey datum). RM2 is a chiseled X on top of the

downstream end of the left abutment footing (elev. $495.25 \mathrm{ft}$, arbitrary survey datum). RM3 is a

nail in a telephone pole $4 \mathrm{ft}$ above the ground, $100 \mathrm{ft}$ from the left end of the bridge on the

bankward side of TH 22 (elev. $499.74 \mathrm{ft}$, arbitrary survey datum).

\begin{tabular}{ccll}
\hline${ }^{1}$ Cross-section & $\begin{array}{c}\text { Section } \\
\text { Reference } \\
\text { Distance } \\
\text { (SRD) } \text { in feet }\end{array}$ & $\begin{array}{c}{ }^{2} \text { Cross-section } \\
\text { development }\end{array}$ & \multicolumn{1}{c}{ Comments } \\
\hline EXTEM & -196 & 1 & $\begin{array}{l}\text { Approach section from } \\
\text { HUNTTH00220033 }\end{array}$ \\
EXIT1 & -196 & 2 & $\begin{array}{l}\text { Modelled additional Exit } \\
\text { section (Templated from }\end{array}$ \\
EXITX & -28 & 1 & $\begin{array}{l}\text { EXTEM) } \\
\text { Exit section }\end{array}$ \\
FULLV & 0 & 2 & $\begin{array}{l}\text { Downstream Full-valley } \\
\text { section (Templated from } \\
\text { EXITX) }\end{array}$ \\
BRIDG & 0 & 1 & Bridge section \\
RDWAY & 8 & 1 & Road Grade section \\
APTEM & 32 & 1 & $\begin{array}{l}\text { Approach section as sur- } \\
\text { veyed (Used as a tem- } \\
\text { plate) }\end{array}$ \\
& & & $\begin{array}{l}\text { Modelled Approach sec- } \\
\text { tion (Templated from } \\
\text { APTEM) }\end{array}$ \\
\hline & 42 & 2 &
\end{tabular}




\section{Data and Assumptions Used in WSPRO Model}

Hydraulic analyses of the reach were done by use of the Federal Highway Administration's WSPRO step-backwater computer program (Shearman and others, 1986, and Shearman, 1990). The analyses reported herein reflect conditions existing at the site at the time of the study. Furthermore, in the development of the model it was necessary to assume no accumulation of debris or ice at the site. Results of the hydraulic model are presented in the Bridge Hydraulic Summary, Appendix B, and figure 7.

Channel roughness factors (Manning's " $n$ ") used in the hydraulic model were estimated using field inspections at each cross section following the general guidelines described by Arcement and Schneider (1989). Final adjustments to the values were made during the modelling of the reach. Channel " $\mathrm{n}$ " values for the reach ranged from 0.050 to 0.060 , and overbank " $n$ " values ranged from 0.045 to 0.090 .

Huntington bridge 33, on Town Highway 22, is located $400 \mathrm{ft}$ downstream of this site. The water surface elevation computed for the approach section of bridge 33 was used as the starting water surface for this model. The surveyed approach section (EXTEM) from bridge 33 was adjusted to account for the difference between the arbitrary datums for the two bridges to establish the modelled exit section (EXIT1). Also because of a tributary entering Brush Brook between the bridge and exit sections of this site, a change in discharge was included. However, it was necessary to reduce the discharge at the exit cross section instead of at the downstream face of the bridge because of the limitations of the WSPRO model.

The surveyed approach section (APTEM) was moved along the approach channel slope $(0.0401 \mathrm{ft} / \mathrm{ft})$ to establish the modelled approach section (APPRO), one bridge length upstream of the upstream face as recommended by Shearman and others (1986). This location also provides a consistent method for determining scour variables. 


\section{Bridge Hydraulics Summary}

$\begin{array}{llll}\text { Average bridge embankment elevation } & 502.5 & f t \\ \text { Average low steel elevation } & 500.0 & f t\end{array}$

100-year discharge $\quad 1,700 \quad \mathrm{ft}^{3} / \mathrm{s}$

Water-surface elevation in bridge opening $\quad 500.0 \quad f t$

Road overtopping? ___ Yes Discharge over road __ $442 \quad \mathrm{ft}^{3} / \mathrm{s}$

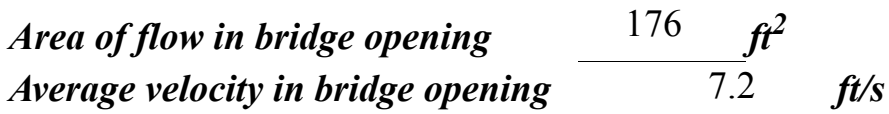

Maximum WSPRO tube velocity at bridge $\quad 9.0 \mathrm{ft} / \mathrm{s}$

Water-surface elevation at Approach section with bridge $\quad 501.0$

Water-surface elevation at Approach section without bridge $\quad 499.1$

Amount of backwater caused by bridge

1.9 it

500-year discharge $\quad 2,220 \quad \mathrm{ft}^{3} / \mathrm{s}$

Water-surface elevation in bridge opening $\quad 500.0 \mathrm{ft}$

Road overtopping? ___ Yes Discharge over road _ $\quad$ _ $\quad .347 / 5$

Area of flow in bridge opening $\quad 176 \quad \mathrm{ft}^{2}$

Average velocity in bridge opening $8.2 \mathrm{ft} / \mathrm{s}$

Maximum WSPRO tube velocity at bridge 10.3 's

Water-surface elevation at Approach section with bridge 501.3

Water-surface elevation at Approach section without bridge $\quad 500.0$

Amount of backwater caused by bridge $1.3, t$

Incipient overtopping discharge $\quad 1,460 \mathrm{ft}^{3} / \mathrm{s}$

Water-surface elevation in bridge opening $497.6 \quad t$

Area of flow in bridge opening $118 \quad \mathrm{ft}^{2}$

Average velocity in bridge opening $\quad 12.4 \quad \mathrm{ft} / \mathrm{s}$

Maximum WSPRO tube velocity at bridge $\quad 15.1 \mathrm{ft} / \mathrm{s}$

Water-surface elevation at Approach section with bridge

Water-surface elevation at Approach section without bridge

500.3

Amount of backwater caused by bridge $\quad 1.5$.t 


\section{Scour Analysis Summary}

\section{Special Conditions or Assumptions Made in Scour Analysis}

Scour depths were computed using the general guidelines described in Hydraulic Engineering Circular 18 (Richardson and others, 1995). Scour depths were calculated assuming an infinite depth of erosive material and a homogeneous particle-size distribution. The results of the scour analysis are presented in tables 1 and 2 and a graph of the scour depths is presented in figure 8 .

Contraction scour for the incipient roadway-overtopping discharge was computed by use of the Laursen clear-water contraction scour equation (Richardson and others, 1995, p. 32 , equation 20). At this site, the 100-year and 500-year discharges resulted in unsubmerged orifice flow. Contraction scour at bridges with orifice flow is best estimated by use of the Chang pressure-flow scour equation (oral communication, J. Sterling Jones, October 4, 1996). Thus, contraction scour for these discharges was computed by use of the Chang equation (Richardson and others, 1995, p. 145-146). The computed streambed armoring depths suggest that armoring will not limit the depth of contraction scour.

For comparison, contraction scour for the discharges resulting in orifice flow was also computed by use of the Laursen clear-water contraction scour equation and the Umbrell pressure-flow equation (Richardson and others, 1995, p. 144) and is presented in Appendix F. Furthermore, for those discharges resulting in unsubmerged orifice flow, contraction scour was computed by substituting estimates for the depth of flow at the downstream bridge face in the contraction scour equations. Results with respect to these substitutions are provided in Appendix F.

Abutment scour was computed by use of the Froehlich equation (Richardson and others, 1995, p. 48, equation 28). Variables for the Froehlich equation include the Froude number of the flow approaching the embankments, the length of the embankment blocking flow, and the depth of flow approaching the embankment less any roadway overtopping. 


\section{Scour Results}
100-yr discharge 500-yr discharge
Incipient overtopping (Scour depths in feet)

Contraction scour:

Main channel

Live-bed scour

Clear-water scour

Depth to armoring

Left overbank

Right overbank

\begin{tabular}{lccr}
-- & -- & -- \\
$7.5^{-}$ & & 0.0 & 0.7 \\
- - $^{--}$ & & $5.0^{-}$ & $17.8^{-}$ \\
-- & $--^{-}$ & -- \\
\hline & -- & -- \\
\hline
\end{tabular}

Local scour:

Abutment scour

9.7

10.9

10.8

Left abutment

8.0-

$9.2-$

6.9

\section{Right abutment}

Pier scour

Pier 1

Pier 2

Pier 3

Abutments:

Left abutment

Right abutment

Piers:

Pier 1

Pier 2

\section{Riprap Sizing}

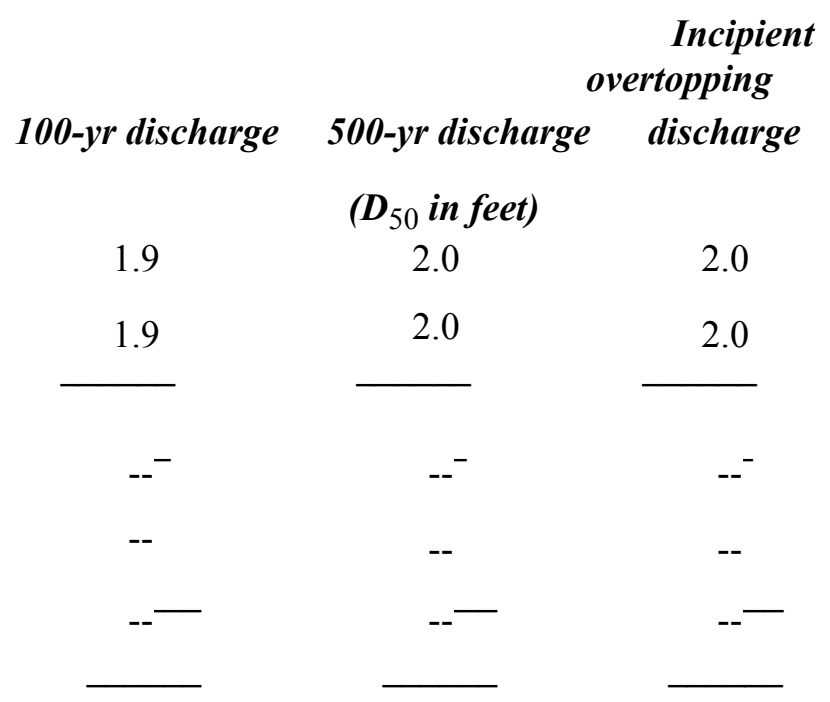




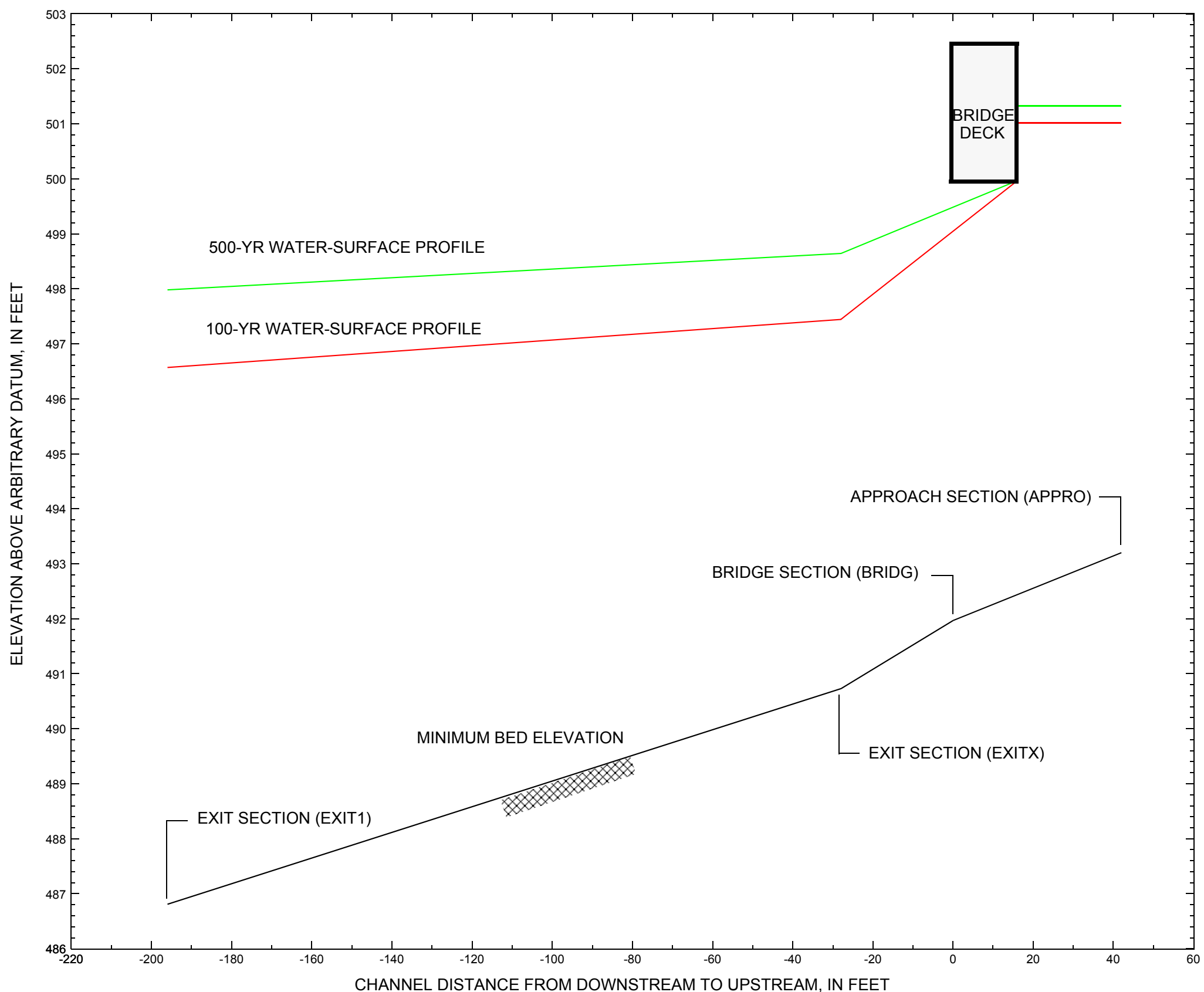

Figure 7. Water-surface profiles for the 100- and 500-yr discharges at structure HUNTTH00210034 on Town Highway 21, crossing Brush Brook, Huntington, Vermont. 


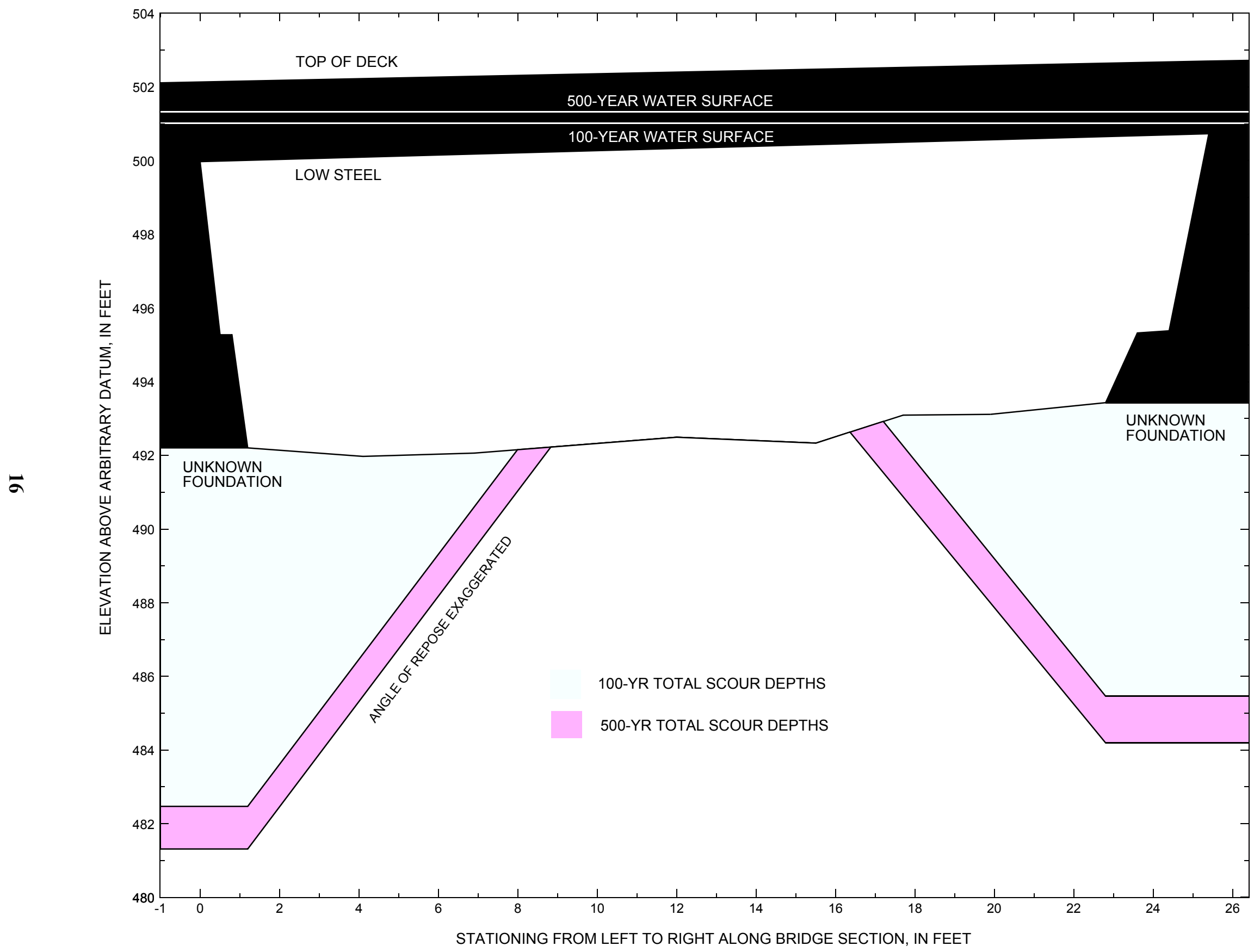

Figure 8. Scour elevations for the 100-yr and 500-yr discharges at structure HUNTTH00210034 on Town Highway 21, crossing Brush Brook, Huntington, Vermont. 
Table 1. Remaining footing/pile depth at abutments for the 100-year discharge at structure HUNTTH00210034 on Town Highway 21, crossing Brush Brook, Huntington, Vermont.

[VTAOT, Vermont Agency of Transportation; --, no data]

\begin{tabular}{|c|c|c|c|c|c|c|c|c|c|c|c|}
\hline Description & Station $^{1}$ & $\begin{array}{l}\text { VTAOT } \\
\text { minimum } \\
\text { low-chord } \\
\text { elevation } \\
\text { (feet) }\end{array}$ & $\begin{array}{l}\text { Surveyed } \\
\text { minimum } \\
\text { low-chord } \\
\text { elevation }{ }^{2} \\
\text { (feet) }\end{array}$ & $\begin{array}{c}\text { Bottom of } \\
\text { footing/pile } \\
\text { elevation }{ }^{2} \\
\text { (feet) }\end{array}$ & $\begin{array}{c}\text { Channel } \\
\text { elevation at } \\
\text { abutment/ } \\
\text { pier }^{2} \\
\text { (feet) }\end{array}$ & $\begin{array}{l}\text { Contraction } \\
\text { scour depth } \\
\text { (feet) }\end{array}$ & $\begin{array}{l}\text { Abutment } \\
\text { scour } \\
\text { depth } \\
\text { (feet) }\end{array}$ & $\begin{array}{l}\text { Pier } \\
\text { scour } \\
\text { depth } \\
\text { (feet) }\end{array}$ & $\begin{array}{l}\text { Depth of } \\
\text { total scour } \\
\text { (feet) }\end{array}$ & $\begin{array}{c}\text { Elevation of } \\
\text { scour }^{2} \\
\text { (feet) }\end{array}$ & $\begin{array}{c}\text { Remaining } \\
\text { footing/pile } \\
\text { depth } \\
\text { (feet) }\end{array}$ \\
\hline \multicolumn{12}{|c|}{100 -yr. discharge is 1,700 cubic-feet per second } \\
\hline Left abutment & 0.0 & 828.4 & 499.97 & -- & 492.2 & 0.0 & 9.7 & -- & 9.7 & 482.5 & -- \\
\hline Right abutment & 25.4 & 828.4 & 500.73 & -- & 493.4 & 0.0 & 8.0 & -- & 8.0 & 485.4 & -- \\
\hline
\end{tabular}

1.Measured along the face of the most constricting side of the bridge.

2.Arbitrary datum for this study.

Table 2. Remaining footing/pile depth at abutments for the 500-year discharge at structure HUNTTH00210034 on Town Highway 21, crossing Brush Brook, Huntington, Vermont.

[VTAOT, Vermont Agency of Transportation; --, no data]

\begin{tabular}{|c|c|c|c|c|c|c|c|c|c|c|c|}
\hline Description & Station $^{1}$ & $\begin{array}{l}\text { VTAOT } \\
\text { minimum } \\
\text { low-chord } \\
\text { elevation } \\
\text { (feet) }\end{array}$ & $\begin{array}{l}\text { Surveyed } \\
\text { minimum } \\
\text { low-chord } \\
\text { elevation } \\
\text { (feet) }\end{array}$ & $\begin{array}{c}\text { Bottom of } \\
\text { footing/pile } \\
\text { elevation }{ }^{2} \\
\text { (feet) }\end{array}$ & $\begin{array}{c}\text { Channel } \\
\text { elevation at } \\
\text { abutment/ } \\
\text { pier }^{2} \\
\text { (feet) }\end{array}$ & $\begin{array}{l}\text { Contraction } \\
\text { scour depth } \\
\text { (feet) }\end{array}$ & $\begin{array}{l}\text { Abutment } \\
\text { scour } \\
\text { depth } \\
\text { (feet) }\end{array}$ & $\begin{array}{l}\text { Pier } \\
\text { scour } \\
\text { depth } \\
\text { (feet) }\end{array}$ & $\begin{array}{l}\text { Depth of } \\
\text { total scour } \\
\quad \text { (feet) }\end{array}$ & $\begin{array}{c}\text { Elevation of } \\
\text { scour }^{2} \\
\text { (feet) }\end{array}$ & $\begin{array}{c}\text { Remaining } \\
\text { footing/pile } \\
\text { depth } \\
\text { (feet) }\end{array}$ \\
\hline \multicolumn{12}{|c|}{500 -yr. discharge is 2,220 cubic-feet per second } \\
\hline Left abutment & 0.0 & 828.4 & 499.97 & -- & 492.2 & 0.0 & 10.9 & -- & 10.9 & 481.3 & -- \\
\hline Right abutment & 25.4 & 828.4 & 500.73 & -- & 493.4 & 0.0 & 9.2 & -- & 9.2 & 484.2 & -- \\
\hline
\end{tabular}

1.Measured along the face of the most constricting side of the bridge.

2.Arbitrary datum for this study. 


\section{SELECTED REFERENCES}

Arcement, G.J., Jr., and Schneider, V.R., 1989, Guide for selecting Manning's roughness coefficients for natural channels and flood plains: U.S. Geological Survey Water-Supply Paper 2339, 38 p.

Barnes, H.H., Jr., 1967, Roughness characteristics of natural channels: U.S. Geological Survey Water-Supply Paper 1849,213 p.

Benson, M. A., 1962, Factors Influencing the Occurrence of Floods in a Humid Region of Diverse Terrain: U.S. Geological Survey WaterSupply Paper 1580-B, 64 p.

Brown, S.A. and Clyde, E.S., 1989, Design of riprap revetment: Federal Highway Administration Hydraulic Engineering Circular No. 11, Publication FHWA-IP-89-016, 156 p.

Federal Highway Administration, 1983, Runoff estimates for small watersheds and development of sound design: Federal Highway Administration Report FHWA-RD-77-158.

Federal Highway Administration, 1993, Stream Stability and Scour at Highway Bridges: Participant Workbook: Federal Highway Administration Report FHWA-HI-91-011.

Froehlich, D.C., 1989, Local scour at bridge abutments in Ports, M.A., ed., Hydraulic Engineering--Proceedings of the 1989 National Conference on Hydraulic Engineering: New York, American Society of Civil Engineers, p. 13-18.

Hayes, D.C.,1993, Site selection and collection of bridge-scour data in Delaware, Maryland, and Virginia: U.S. Geological Survey WaterResources Investigation Report 93-4017, 23 p.

Interagency Advisory Committee on Water Data, 1982, Guidelines for determining flood flow frequency: U.S. Geological Survey, Bulletin 17B of the Hydrology Subcommittee, 190 p.

Johnson, C.G. and Tasker, G.D.,1974, Progress report on flood magnitude and frequency of Vermont streams: U.S. Geological Survey OpenFile Report 74-130, 37 p.

Lagasse, P.F., Schall, J.D., Johnson, F., Richardson, E.V., Chang, F., 1995, Stream Stability at Highway Structures: Federal Highway Administration Hydraulic Engineering Circular No. 20, Publication FHWA-IP-90-014, 144 p.

Laursen, E.M., 1960, Scour at bridge crossings: Journal of the Hydraulics Division, American Society of Civil Engineers, v. 86, no. HY2, p. 39-53.

Potter, W. D., 1957a, Peak rates of runoff in the Adirondack, White Mountains, and Maine woods area, Bureau of Public Roads

Potter, W. D., 1957b, Peak rates of runoff in the New England Hill and Lowland area, Bureau of Public Roads

Richardson, E.V. and Davis, S.R., 1995, Evaluating scour at bridges: Federal Highway Administration Hydraulic Engineering Circular No. 18, Publication FHWA-IP-90-017, 204 p.

Richardson, E.V., Simons, D.B., and Julien, P.Y., 1990, Highways in the river environment: Federal Highway Administration Publication FHWA-HI-90-016.

Ritter, D.F., 1984, Process Geomorphology: W.C. Brown Co., Debuque, Iowa, 603 p.

Shearman, J.O., 1990, User's manual for WSPRO--a computer model for water surface profile computations: Federal Highway Administration Publication FHWA-IP-89-027, 187 p.

Shearman, J.O., Kirby, W.H., Schneider, V.R., and Flippo, H.N., 1986, Bridge waterways analysis model; research report: Federal Highway Administration Publication FHWA-RD-86-108, 112 p.

Talbot, A.N., 1887, The determination of water-way for bridges and culverts.

U.S. Department of Transportation, 1993, Stream stability and scour at highway bridges, Participant Workbook: Federal Highway Administration Publication FHWA HI-91-011.

U.S. Geological Survey, 1948, Huntington, Vermont 7.5 Minute Series quadrangle map: U.S. Geological Survey Topographic Maps, Photorevised 1980, Scale 1:24,000. 


\section{APPENDIX A: \\ WSPRO INPUT FILE}




\section{WSPRO INPUT FILE}

U.S. Geological Survey WSPRO Input File hunt034.wsp Hydraulic analysis for structure HUNTTH00210034 Date: 17-JUN-97 TH 21 CROSSING BRUSH BROOK IN HUNTINGTON, VT

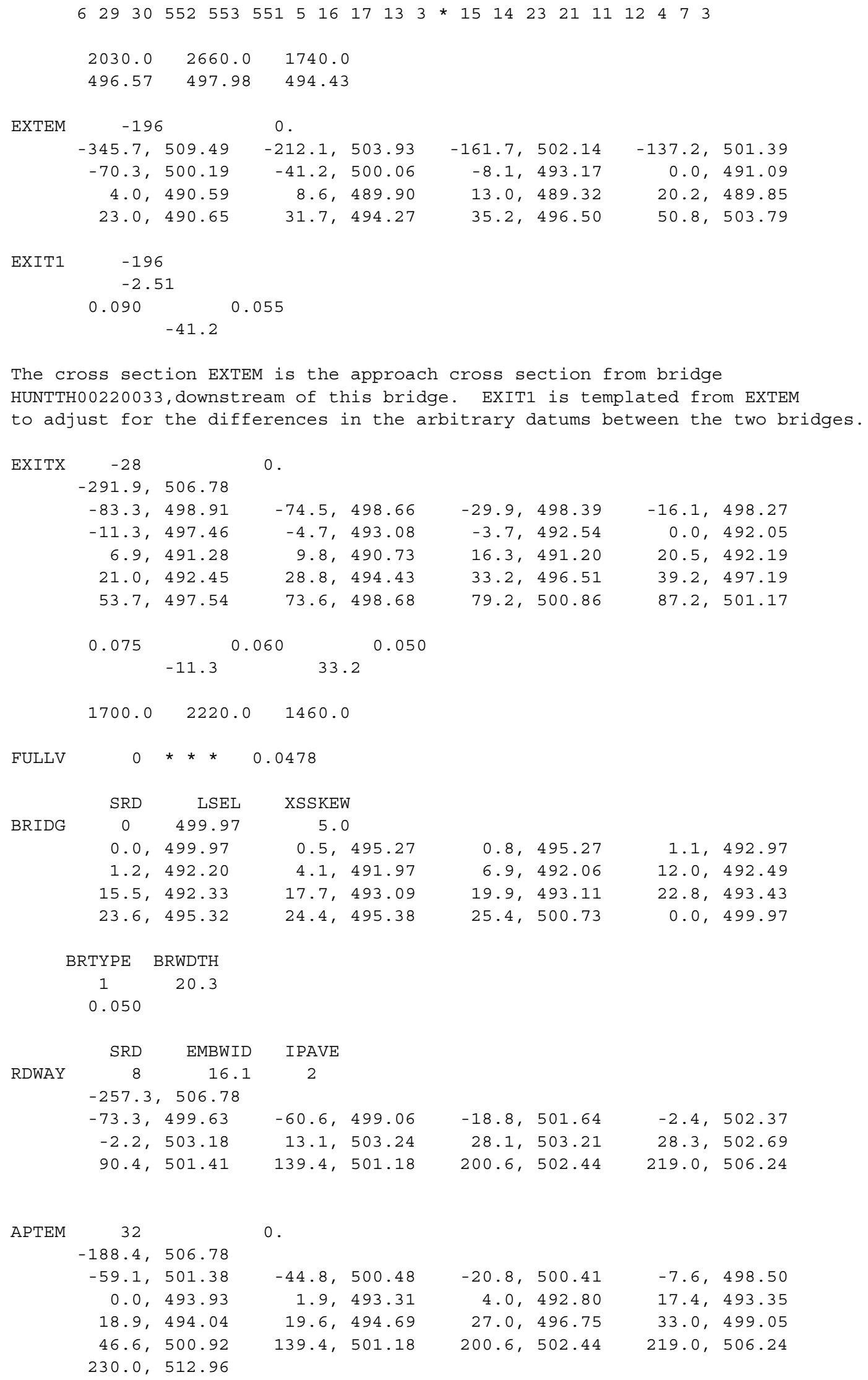

0 .

$\begin{array}{rrrr}-44.8,500.48 & -20.8,500.41 & -7.6,498.50 \\ 1.9,493.31 & 4.0,492.80 & 17.4,493.35 \\ 19.6,494.69 & 27.0,496.75 & 33.0,499.05 \\ 139.4,501.18 & 200.6,502.44 & 219.0,506.24\end{array}$


WSPRO INPUT FILE (continued)

$\begin{array}{lrrrrr}* & \text { AS } & \text { APPRO } & 42 & * * * & 0.0401 \\ \text { GT } & & & & & \\ \text { N } & 0.075 & & 0.060 & & 0.045 \\ \text { SA } & & & -7.6 & 33.0 & \end{array}$

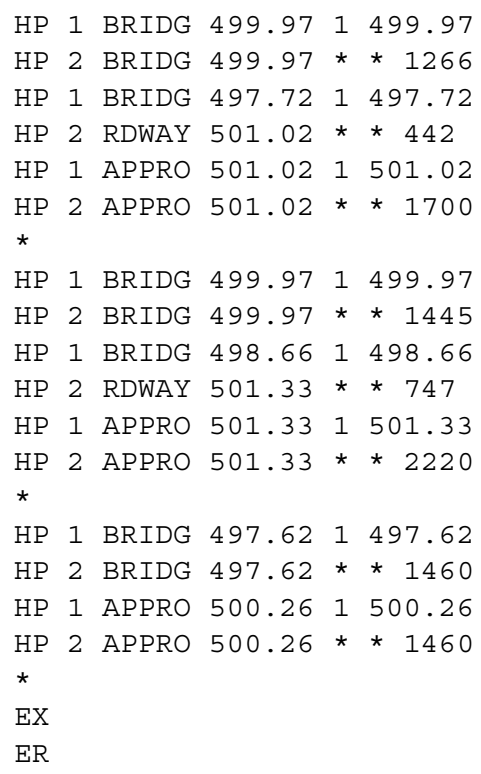




\section{APPENDIX B: \\ WSPRO OUTPUT FILE}




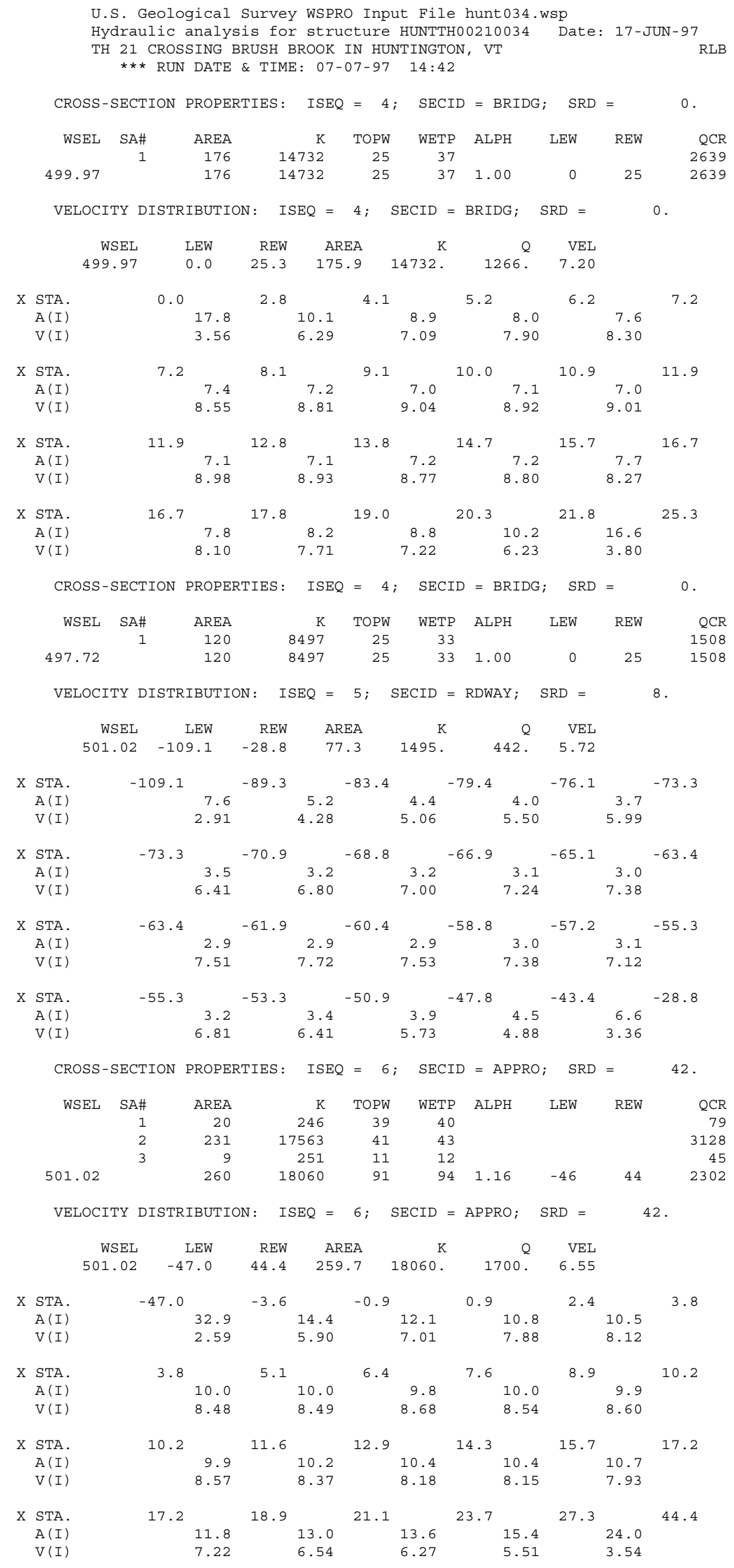




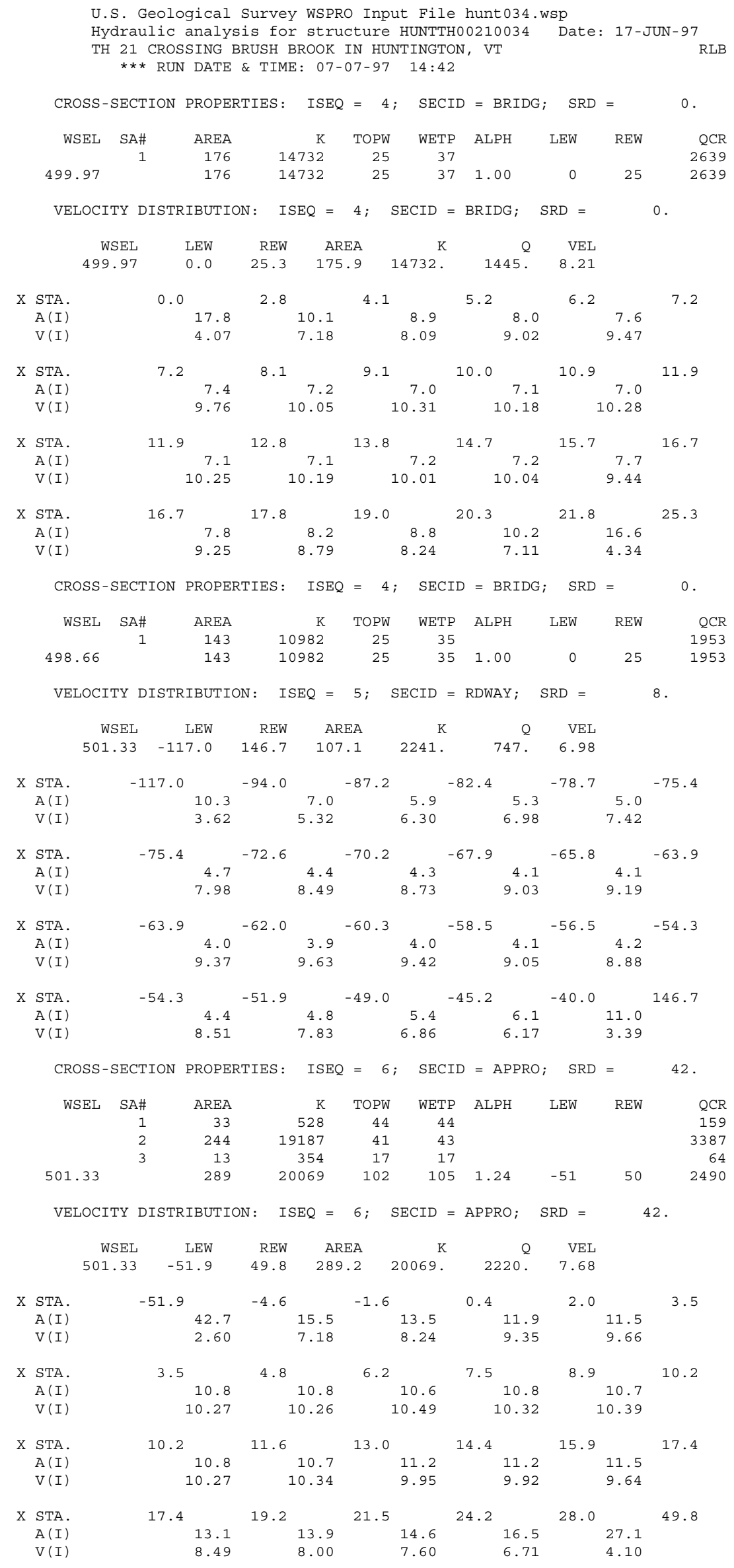


WSPRO OUTPUT FILE (continued)

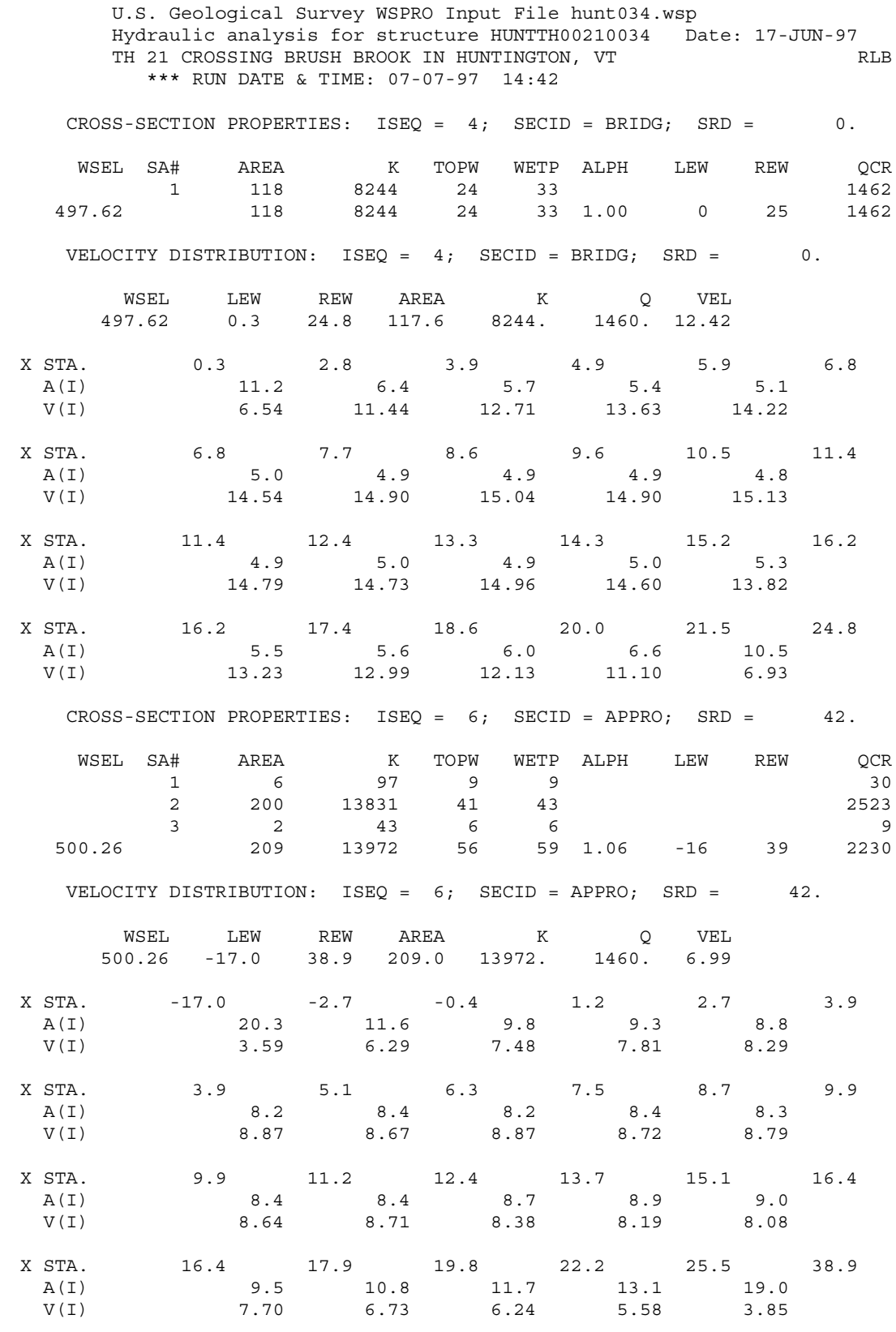


WSPRO OUTPUT FILE (continued)

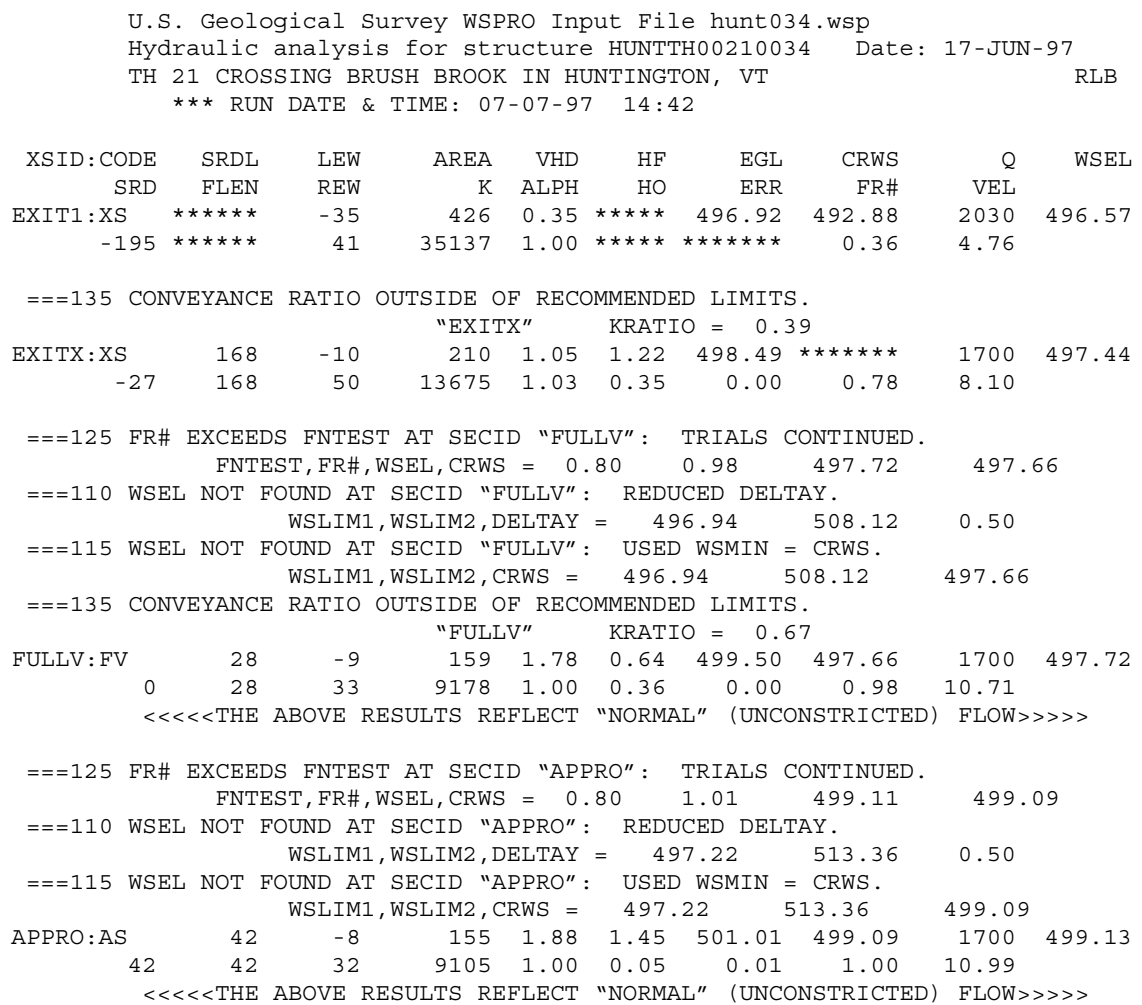

$===215$ FLOW CLASS 1 SOLUTION INDICATES POSSIBLE ROAD OVERFLOW.

$$
\begin{array}{llccc}
\text { WS1, WSSD , WS 3, RGMIN }= & 501.03 & 0.00 & 498.13 & 499.06
\end{array}
$$

$==260$ ATTEMPTING FLOW CLASS 4 SOLUTION.

$==240$ NO DISCHARGE BALANCE IN 15 ITERATIONS.

$$
\text { WS, QBO, QRD = } 502.56 \quad 0 . \quad 1700 .
$$

$==280$ REJECTED FLOW CLASS 4 SOLUTION

$===245$ ATTEMPTING FLOW CLASS 2 (5) SOLUTION

$<<<<$ RESULTS REFLECTING THE CONSTRICTED FLOW FOLLOW $>>>>>$

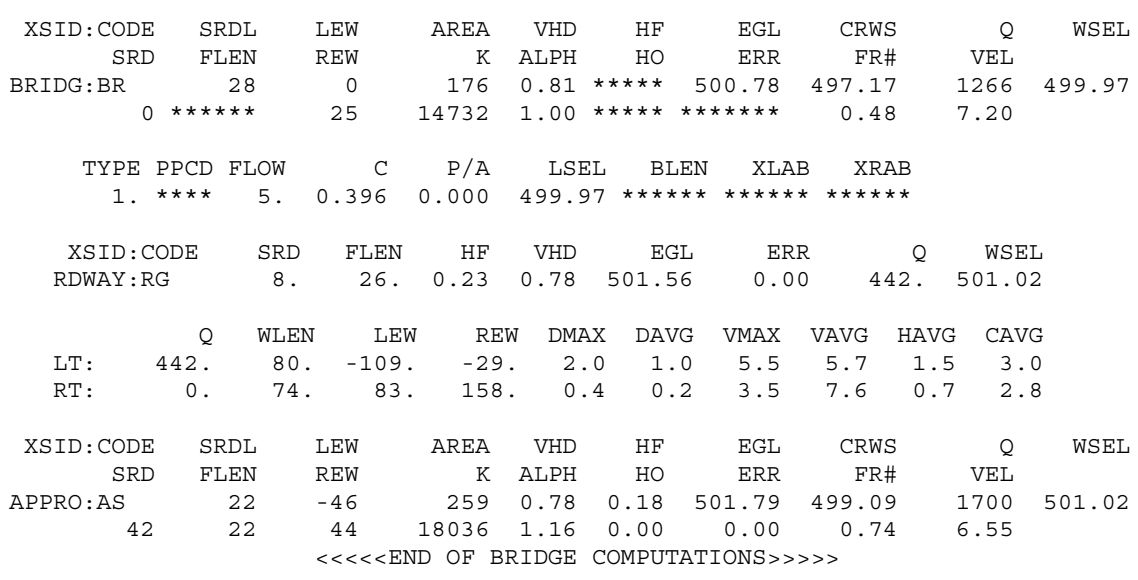

FIRST USER DEFINED TABLE.

$\begin{array}{lrrrrrrrr}\text { XSID : CODE } & \text { SRD } & \text { LEW } & \text { REW } & Q & \text { K } & \text { AREA } & \text { VEL } & \text { WSEL } \\ \text { EXIT1: XS } & -196 . & -36 . & 41 . & 2030 . & 35137 . & 426 . & 4.76 & 496.57 \\ \text { EXITX :XS } & -28 . & -11 . & 50 . & 1700 . & 13675 . & 210 . & 8.10 & 497.44 \\ \text { FULLV : FV } & 0 . & -10 . & 33 . & 1700 . & 9178 . & 159 . & 10.71 & 497.72 \\ \text { BRIDG : BR } & 0 . & 0 . & 25 . & 1266 . & 14732 . & 176 . & 7.20 & 499.97 \\ \text { RDWAY : RG } & 8 . * * * * * * * & 442 . & 442 . * * * * * * * * & 0 . & 2.00 & 501.02 \\ \text { APPRO : AS } & 42 . & -47 . & 44 . & 1700 . & 18036 . & 259 . & 6.55 & 501.02\end{array}$

SECOND USER DEFINED TABLE.

$\begin{array}{lcrrrrrrrr}\text { XSID : CODE } & \text { CRWS } & \text { FR\# } & \text { YMIN } & \text { YMAX } & \text { HF } & \text { HO } & \text { VHD } & \text { EGL } & \text { WSEL } \\ \text { EXIT1 :XS } & 492.88 & 0.36 & 486.81 & 506.98 * * * * * * * * * * & 0.35 & 496.92 & 496.57 \\ \text { EXITX:XS } & * * * * * * * * & 0.78 & 490.73 & 506.78 & 1.22 & 0.35 & 1.05 & 498.49 & 497.44 \\ \text { FULLV :FV } & 497.66 & 0.98 & 492.07 & 508.12 & 0.64 & 0.36 & 1.78 & 499.50 & 497.72 \\ \text { BRIDG : BR } & 497.17 & 0.48 & 491.97 & 500.73 * * * * * * * * * * * & 0.81 & 500.78 & 499.97 \\ \text { RDWAY : RG } & * * * * * * * * * * * * * * * * & 499.06 & 506.78 & 0.23 * * * * * * & 0.78 & 501.56 & 501.02 \\ \text { APPRO :AS } & 499.09 & 0.74 & 493.20 & 513.36 & 0.18 & 0.00 & 0.78 & 501.79 & 501.02\end{array}$


WSPRO OUTPUT FILE (continued)

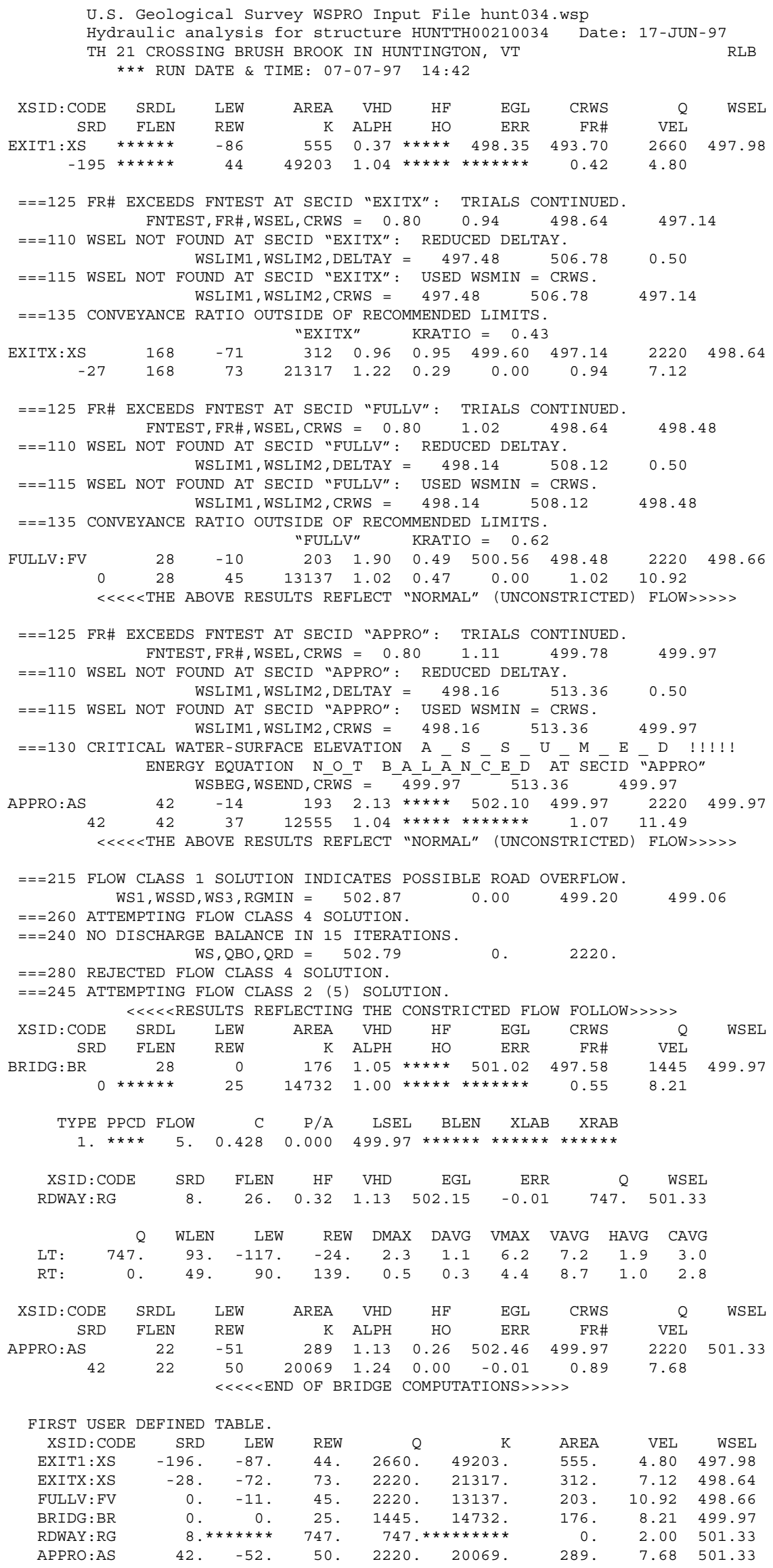


WSPRO OUTPUT FILE (continued)

\begin{tabular}{|c|c|c|c|c|c|c|c|c|c|}
\hline XSID : CODE & CRWS & FR\# & YMIN & YMAX & $\mathrm{HF}$ & $\mathrm{HO}$ & VHD & EGL & WSEL \\
\hline EXIT1:XS & 493.70 & 0.42 & 486.81 & 506.98 & $\star \star \star \star \star *$ & $\star \star \star \star * *$ & 0.37 & 498.35 & 497.98 \\
\hline EXITX:XS & 497.14 & 0.94 & 490.73 & 506.78 & 0.95 & 0.29 & 0.96 & 499.60 & 498.64 \\
\hline FULLV : FV & 498.48 & 1.02 & 492.07 & 508.12 & 0.49 & 0.47 & 1.90 & 500.56 & 498.66 \\
\hline BRIDG : BR & 497.58 & 0.55 & 491.97 & 500.73 & $\star \star \star \star \star *$ & $\star \star \star \star * *$ & 1.05 & 501.02 & 499.97 \\
\hline RDWAY : RG & 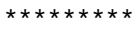 & $* * * * *$ & 499.06 & 506.78 & 0.32 & $\star \star \star * *$ & 1.13 & 502.15 & 501.33 \\
\hline APPRO: AS & 499.97 & 0.89 & 493.20 & 513.36 & 0.26 & 0.00 & 1.13 & 502.46 & 501.33 \\
\hline
\end{tabular}

U.S. Geological Survey WSPRO Input File hunt034.wsp

Hydraulic analysis for structure HUNTTH00210034 Date: 17-JUN-97

TH 21 CROSSING BRUSH BROOK IN HUNTINGTON, VT

*** RUN DATE \& TIME: 07-07-97 14:42

$\begin{array}{rrrrrrrrrr}\text { XSID : CODE } & \text { SRDL } & \text { LEW } & \text { AREA } & \text { VHD } & \text { HF } & \text { EGL } & \text { CRWS } & \text { Q } & \text { WSEL } \\ \text { SRD } & \text { FLEN } & \text { REW } & \text { K } & \text { ALPH } & \text { HO } & \text { ERR } & \text { FR\# } & \text { VEL } & \\ \text { EXIT1:XS } & * * * * * * & -25 & 277 & 0.61 * * * * * & 495.04 & 492.46 & 1740 & 494.43 \\ -195 & * * * * * * & 36 & 19764 & 1.00 & * * * * * * * * * * * & 0.53 & 6.2 & \end{array}$

$===125$ FR\# EXCEEDS FNTEST AT SECID "EXITX": TRIALS CONTINUED.

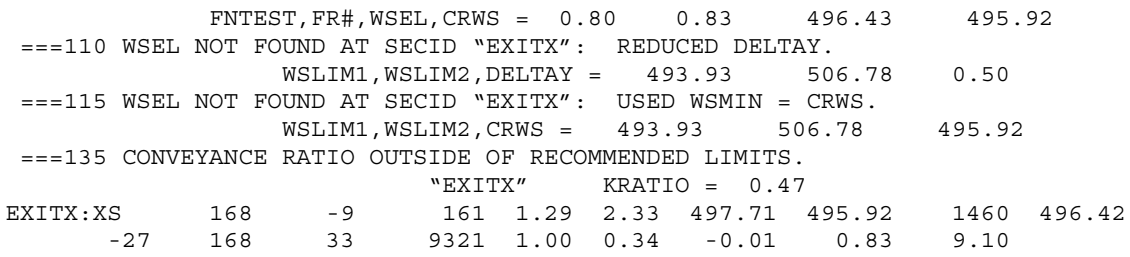

$===125$ FR\# EXCEEDS FNTEST AT SECID "FULLV": TRIALS CONTINUED.

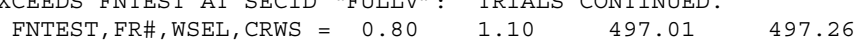
$==110$ WSEL NOT FOUND AT SECID "FULLV": REDUCED DELTAY WSLIM1, WSLIM2, DELTAY $=495.92 \quad 508.12 \quad 0.50$ $==115$ WSEL NOT FOUND AT SECID "FULLV": USED WSMIN = CRWS WSLIM1, WSLIM2, CRWS $=495.92 \quad 508.12 \quad 497.26$

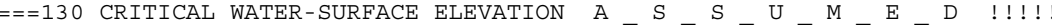
ENERGY EQUATION $\mathrm{N} O \mathrm{~T}$ B A L $\overline{\mathrm{A}} \mathrm{N} \overline{\mathrm{C}}$ E $\overline{\mathrm{D}}$ AT $\mathrm{TE} \overline{\mathrm{C}} I \mathrm{D}$ "FULLV"

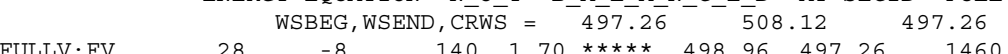
$\begin{array}{rrrrrrr}28 & -8 & 140 & 1.70 \\ 28 & 32 & 7623 & 1.00 * * * * * * * * * * * * & 1.00 & 10.46 & \end{array}$ $<<<<$ THE ABOVE RESULTS REFLECT "NORMAL" (UNCONSTRICTED) FLOW >>>>>

\begin{tabular}{|c|c|c|c|c|c|c|c|c|c|c|}
\hline$==125$ & FR\# & $\begin{array}{r}\text { EXCEE } \\
\text { FNT }\end{array}$ & $\begin{array}{l}\text { DDS FNTEST } \\
\text { CEST, FR\#, }\end{array}$ & $\begin{array}{l}\text { I AT SECI } \\
\text { NSEL, CRWS }\end{array}$ & $\begin{array}{l}\text { D "APPR } \\
=\quad 0.8\end{array}$ & $\begin{array}{l}\mathrm{RO}^{\prime \prime}: \\
80\end{array}$ & $\begin{array}{l}\text { TRIALS } \\
0.97\end{array}$ & 498.76 & \multicolumn{2}{|c|}{498.67} \\
\hline$===110$ & WSEL & NOT & FOUND AT & SECID "A & PPRO" : & REDUC & CED DELT & TAY. & & \\
\hline & & & WSLIM1, & WSLIM2, DI & ELTAY = & 496 & 6.76 & 513.36 & 0.50 & \\
\hline$===115$ & WSEL & NOT & FOUND AT & SECID "A & PPRO" : & USED & WSMIN & $=$ CRWS. & & \\
\hline & & & WSLIM1, & WSLIM2, C & RWS $=$ & 496.7 & 76 & 513.36 & 498.67 & \\
\hline APPRO:AS & & 42 & -6 & 140 & 1.69 & 1.49 & 500.45 & 498.67 & 1460 & 498.76 \\
\hline & 42 & 42 & 31 & 7896 & 1.00 & 0.00 & 0.01 & 0.96 & 10.42 & \\
\hline & & THE & ABOVE RE & ESULTS RE & FLECT " & "NORMAI & (UNCC & ONSTRICTED) & FLOW $>>$ & \\
\hline
\end{tabular}

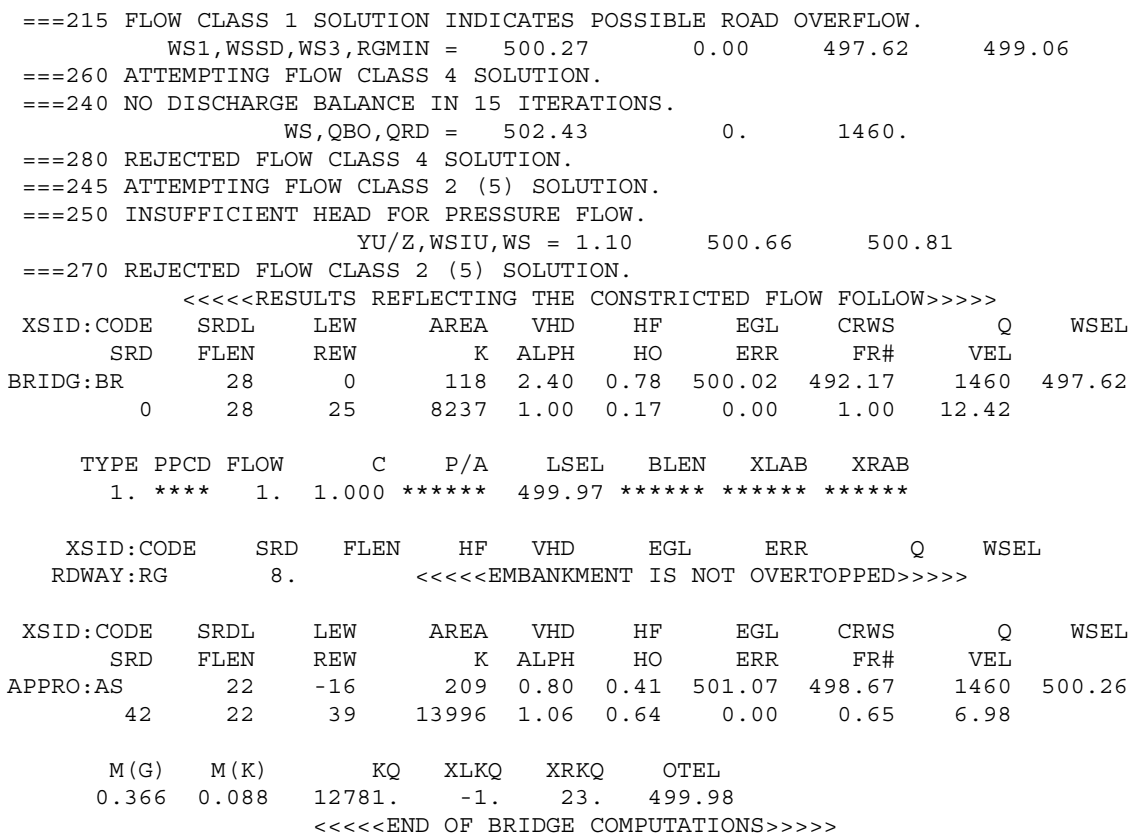


WSPRO OUTPUT FILE (continued)

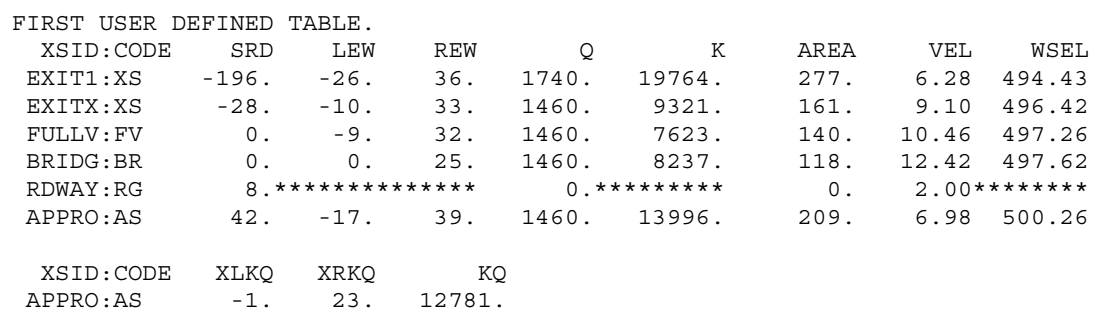

SECOND USER DEFINED TABLE.

$\begin{array}{lcrrrrrrrr}\text { XSID : CODE } & \text { CRWS } & \text { FR\# } & \text { YMIN } & \text { YMAX } & \text { HF } & \text { HO } & \text { VHD } & \text { EGL } & \text { WSEL } \\ \text { EXIT1 :XS } & 492.46 & 0.53 & 486.81 & 506.98 * * * * * * * * * * * & 0.61 & 495.04 & 494.43 \\ \text { EXITX:XS } & 495.92 & 0.83 & 490.73 & 506.78 & 2.33 & 0.34 & 1.29 & 497.71 & 496.42 \\ \text { FULLV : FV } & 497.26 & 1.00 & 492.07 & 508.12 * * * * * * * * * * & 1.70 & 498.96 & 497.26 \\ \text { BRIDG : BR } & 492.17 & 1.00 & 491.97 & 500.73 & 0.78 & 0.17 & 2.40 & 500.02 & 497.62 \\ \text { RDWAY : RG } & * * * * * * * * * * * * * * & 499.06 & 506.78 * * * * * * * * * * & 0.62 & 501.24 * * * * * * * \\ \text { APPRO :AS } & 498.67 & 0.65 & 493.20 & 513.36 & 0.41 & 0.64 & 0.80 & 501.07 & 500.26\end{array}$




\section{APPENDIX C:}

\section{BED-MATERIAL PARTICLE-SIZE DISTRIBUTION}




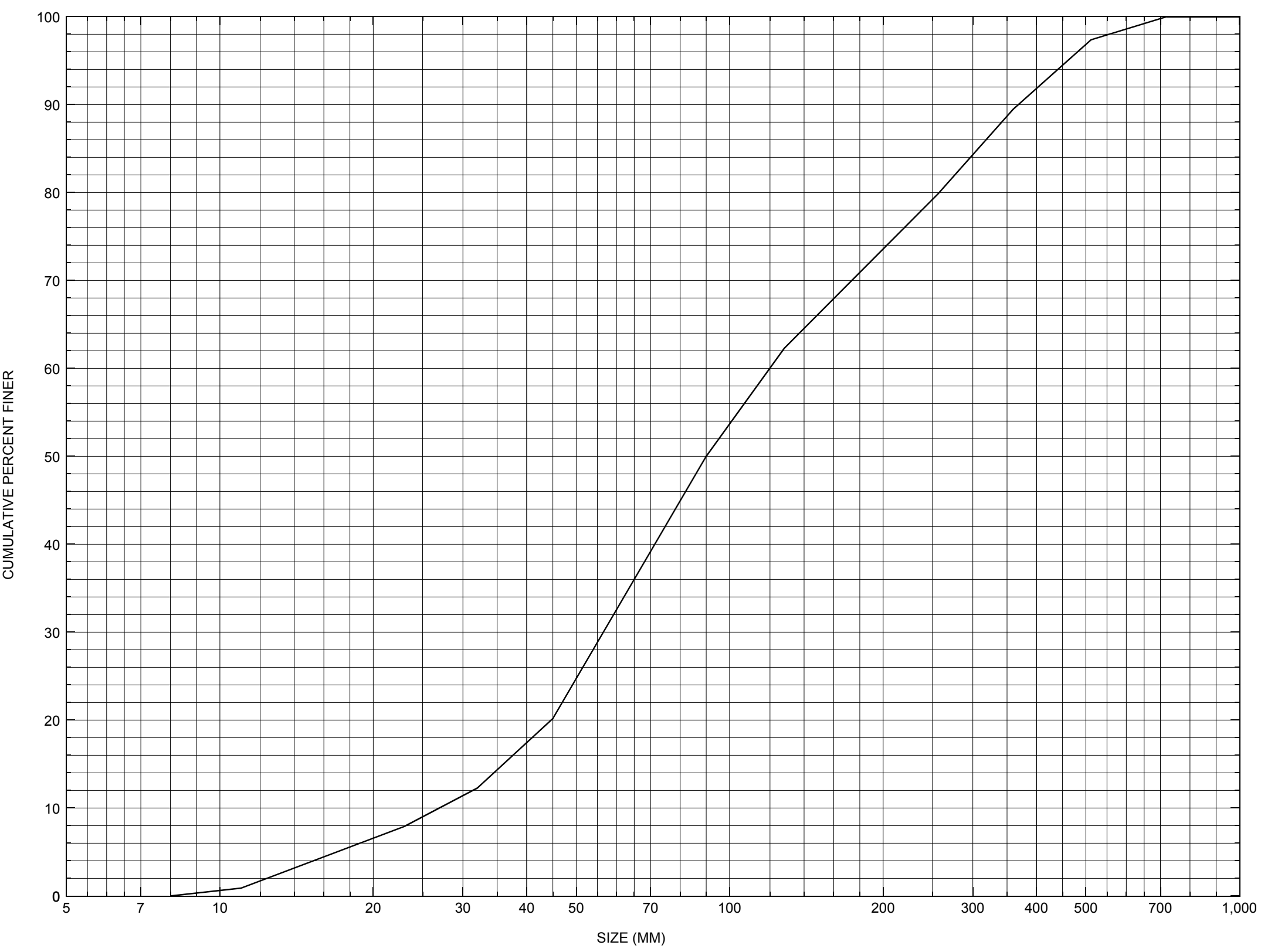

Appendix C. Bed material particle-size distribution for a pebble count in the channel approach of structure HUNTTH00210034, in Huntington, Vermont. 


\section{APPENDIX D: \\ HISTORICAL DATA FORM}




\section{Structure Number HUNTTH00210034}

\section{General Location Descriptive}

Data collected by (First Initial, Full last name) $\underline{\mathbf{L}}$. Medalie

Date $(M M / D D / Y Y) \_11 / \underline{30} / \underline{95}$

Highway District Number $(I-2 ; n n) \underline{\mathbf{0 5}}$

Town (FIPS place code; I - 4; nnnnn) $\mathbf{3 4 6 0 0}$

Waterway (I - 6) BRUSH BROOK

Route Number $\mathbf{C 3 0 2 1}$

Topographic Map Huntington

Latitude (I - 16; nnnn.n) 44179
County (FIPS county code; I - 3; nnn)

Mile marker (I - 11; nnn.nnn) $\mathbf{0 0 0 0 0 0}$

Road Name (I - 7): -

Vicinity (I - 9) 0.01 MI TO JCT W C3 TH22

Hydrologic Unit Code: $\mathbf{0 2 0 1 0 0 3}$

Longitude (i - 17; nnnnn.n) $\mathbf{7 2 5 6 9}$

\section{Select Federal Inventory Codes}

FHWA Structure Number $(I$ - 8) $\mathbf{1 0 0 4 0 8 0 0 3 4 0 4 0 8}$

Maintenance responsibility $(I-21 ; n n) \quad \mathbf{0 3} \quad$ Maximum span length $(I-48 ; n n n n) \underline{\mathbf{0 0 2 6}}$

Year built (I - 27; YYYY) 1950

Structure length (I - 49; nnnnnn) $\underline{\mathbf{0 0 0 0 2 8}}$

Average daily traffic, ADT (I - 29; nnnnnn) $\underline{000010}$ Deck Width (I- 52; nn.n) 161

Year of ADT (I - 30; YY) $\mathbf{9 3}$

Channel \& Protection $(I-61 ; n) \underline{5}$

Opening skew to Roadway $(I-34 ; n n) \quad \mathbf{0 2}$

Waterway adequacy $(I-71 ; n)$

Operational status $(I-41 ; X) \quad \mathbf{P}$

Underwater Inspection Frequency $(I-92 B ; X Y Y) \_\mathbf{N}$

Structure type (I- 43; nnn) $\mathbf{3 0 2}$

Year Reconstructed (I - 106) $\mathbf{0 0 0 0}$

Approach span structure type (I - 44; nnn) $\mathbf{0 0 0}$

Clear span (nnn.n ft) $\mathbf{2 3}$

Number of spans (I - 45; nnn) $\mathbf{0 0 1}$

Vertical clearance from streambed (nnn.n ft) $\underline{7}$

Number of approach spans (I-46; nnnn) $\underline{\mathbf{0 0 0 0}}$ Waterway of full opening $\left(n n n . n \mathrm{ft}^{2}\right) \underline{\mathbf{1 6 1}}$

Comments:

According to the structural inspection report dated 11/1/93, this structure is a steel beam stringer with a wood deck. The abutments and footings are concrete. The DS right wingwall has sheet metal backwalls, which are rusted. A $1 \mathrm{ft}$ void is present along the bottom of the LABUT footing at the DS end, and is possibly the result of an encased boulder slipping out. A concrete footing has recently been poured along the bottom of the RABUT to correct the spalling problem. Large boulders have been placed on the embankments at the US end of both abutments. The DS end of the LABUT has eroded some, with a few boulders showing. An additional small stream flows in near the DS end of the RABUT. 


\section{Bridge Hydrologic Data}

Is there hydrologic data available? $\underline{\mathbf{Y}}$ if No, type ctrl- $h \quad$ VTAOT Drainage area $\left(m i^{2}\right): \underline{\mathbf{6 . 1}}$

Terrain character: Hilly to mountainous, mostly forested

Stream character \& type: -

Streambed material: Stone and gravel

Discharge Data (cfs): $\quad \mathrm{Q}_{2.33} \stackrel{\mathbf{4 0 0}}{\mathbf{1 5 0 0}}$

$\mathrm{Q}_{50} \mathbf{1 5 0 0}$

$\begin{array}{lll}\mathrm{Q}_{10} \frac{\mathbf{9 0 0}}{\mathbf{1 8 0 0}} & \mathrm{Q}_{25} \stackrel{1200}{ } \\ \mathrm{Q}_{100} & \mathrm{Q}_{500}\end{array}$

Record flood date (MM /DD/YY): - $/$ - $/$ -

Water surface elevation $(f t):-$

Estimated Discharge (cfs): Velocity at $\mathrm{Q}$ $(\mathrm{ft} / \mathrm{s}):$

Ice conditions (Heavy, Moderate, Light) : -

Debris (Heavy, Moderate, Light):

The stage increases to maximum highwater elevation (Rapidly, Not rapidly):

The stream response is (Flashy, Not flashy):

Describe any significant site conditions upstream or downstream that may influence the stream's stage: Interagency memo in hydraulics report dated 12/13/94, states that the existing bridge constricts the channel and has a history of scour problems. The scour problems at this bridge are caused, in part, by the location of the bridge in relation to the confluence with the small brook to the east.

Watershed storage area (in percent): 1

The watershed storage area is: - _ (1-mainly at the headwaters; 2- uniformly distributed; 3-immediatly upstream oi the site)

Water Surface Elevation Estimates for Existing Structure:

\begin{tabular}{|l|l|c|c|l|l|}
\hline Peak discharge frequency & $Q_{2.33}$ & $Q_{10}$ & $Q_{25}$ & $Q_{50}$ & $Q_{100}$ \\
Water surface elevation (ft)) & $\mathbf{2 5 1 . 2 7}$ & $\mathbf{2 5 1 . 8 5}$ & $\mathbf{2 5 2 . 1 6}$ & $\mathbf{2 5 2 . 4 6}$ & $\mathbf{2 5 2 . 8 1}$ \\
Velocity $(\mathrm{ft} / \mathrm{sec})$ & - & - & - & - & - \\
\hline
\end{tabular}

Long term stream bed changes: Elevations are in meters.

Is the roadway overtopped below the $\mathrm{Q}_{100}$ ? (Yes, No, Unknown): $\mathbf{U}$ Frequency: -

Relief Elevation $(f t)$ :

Discharge over roadway at $\mathrm{Q}_{100}\left(\mathrm{ft}^{3} / \mathrm{sec}\right)$ : -

Are there other structures nearby? (Yes, No, Unknown): $\mathbf{Y}$ If No or Unknown, type ctrl-n os Upstream distance (miles): Highway No. : $\mathbf{T H 2 2}$ Town: Huntington Year Built: 1925 Clear span (ft): $\underline{\mathbf{3 5}}$ Clear Height $(f t): \underline{\mathbf{1 0}}$ Full Waterway $\left(f t^{2}\right): \underline{\mathbf{3 5 0}}$ Structure No. : 32 Structure Type: I-beam 1925 
Downstream distance (miles): $\mathbf{. 0 5}$ Town: Huntington

Highway No. : TH22 Structure No. : 33 Structure Type:

Clear span (ft): $\mathbf{3 0}$ Clear Height $(f t): \underline{8}$ Full Waterway $\left(f^{2}\right): \underline{240}$

Comments:

\section{USGS Watershed Data}

Watershed Hydrographic Data

Drainage area $(D A)$

Watershed storage (ST)

Bridge site elevation

Main channel length

820

4.03

$10 \%$ channel length elevation $\mathbf{8 8 0}$

Main channel slope

(S) 601.00 $\mathrm{ft} / \mathrm{mi}$

Watershed Precipitation Data

Average site precipitation in Average headwater precipitation in

Maximum 2yr-24hr precipitation event $(124,2)$ in

Average seasonal snowfall (Sn) $\mathrm{ft}$ 


\section{Bridge Plan Data}

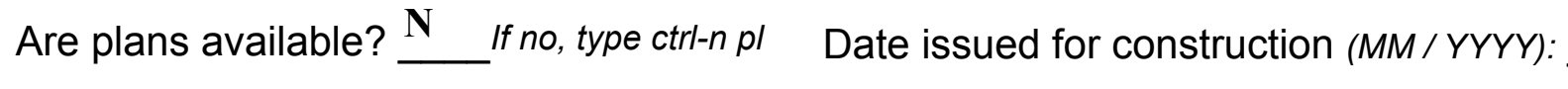

Project Number

Minimum channel bed elevation:

Low superstructure elevation: USLAB DSLAB USRAB DSRAB Benchmark location description:

NO BENCKMARK INFORMATION

Reference Point (MSL, Arbitrary, Other):

Datum (NAD27, NAD83, Other):

Foundation Type: 4

If 1: Footing Thickness

If 2: Pile Type: (1-Wood; 2-Steel or metal; 3-Concrete)

If 3 : Footing bottom elevation:

Is boring information available? $\mathbf{N}$ Foundation Material Type: $\underline{3}$

(1-Spreadfooting; 2-Pile; 3- Gravity; 4-Unknown)

Footing bottom elevation: -

Briefly describe material at foundation bottom elevation or around piles:

NO DRILL BORING INFORMATION

Comments:

Note on hydraulics report dated 12/94, bot. bms=252.50 meters; chan. bot. @approach=250.39 meters. The average low superstructure elevation is 252.5 meters.
Approximate pile driven length: If no, type ctrl-n bi Number of borings taken: (1-regolith, 2-bedrock, 3-unknown) 


\section{Cross-sectional Data}

Is cross-sectional data available? $\underline{\mathbf{Y}}$

If no, type ctrl-n xs

Source (FEMA, VTAOT, Other)? VTAOT

This cross section is the upstream face. The low cord to bed length data is from the sketch Comments: attached to a bridge inspection report dated 11/01/93. The sketch was done on 11/02/93.

There is no accurate low cord elevation data of the upstream face available.

\begin{tabular}{|l|l|l|l|l|l|l|l|l|l|l|l|}
\hline Station & $\mathbf{0}$ & $\mathbf{1}$ & $\mathbf{9}$ & $\mathbf{1 6}$ & $\mathbf{2 2}$ & $\mathbf{2 3}$ & - & - & - & - & - \\
\hline Feature & LAB & - & - & - & - & RAB & - & - & - & - & - \\
\hline $\begin{array}{l}\text { Low cord } \\
\text { elevation }\end{array}$ & - & - & - & - & - & - & - & - & - & - & - \\
\hline $\begin{array}{l}\text { Bed } \\
\text { elevation }\end{array}$ & - & - & - & - & - & - & - & - & - & - & - \\
\hline $\begin{array}{l}\text { Low cord to } \\
\text { bed length }\end{array}$ & $\mathbf{4 . 5}$ & $\mathbf{7 . 1}$ & $\mathbf{8 . 1}$ & $\mathbf{7 . 6}$ & $\mathbf{7 . 6}$ & $\mathbf{5 . 2}$ & - & - & - & - & - \\
\hline Station & - & - & - & - & - & - & - & - & - & - & - \\
\hline Feature & - & - & - & - & - & - & - & - & - & - & - \\
\hline $\begin{array}{l}\text { Low cord } \\
\text { elevation }\end{array}$ & - & - & - & - & - & - & - & - & - & - & - \\
\hline $\begin{array}{l}\text { Bed } \\
\text { elevation }\end{array}$ & - & - & - & - & - & - & - & - & - & - & - \\
\hline $\begin{array}{l}\text { Low cord to } \\
\text { bed length }\end{array}$ & - & - & - & - & - & - & - & - & - & - & - \\
\hline
\end{tabular}

Source (FEMA, VTAOT, Other)?

Comments:

\begin{tabular}{|l|l|l|l|l|l|l|l|l|l|l|l|}
\hline Station & - & - & - & - & - & - & - & - & - & - & - \\
\hline Feature & - & - & - & - & - & - & - & - & - & - & - \\
\hline $\begin{array}{l}\text { Low cord } \\
\text { elevation }\end{array}$ & - & - & - & - & - & - & - & - & - & - & - \\
\hline $\begin{array}{l}\text { Bed } \\
\text { elevation }\end{array}$ & - & - & - & - & - & - & - & - & - & - & - \\
\hline $\begin{array}{l}\text { Low cord to } \\
\text { bed length }\end{array}$ & - & - & - & - & - & - & - & - & - & - & - \\
\hline Station & - & - & - & - & - & - & - & - & - & - & - \\
\hline Feature & - & - & - & - & - & - & - & - & - & - & - \\
\hline $\begin{array}{l}\text { Low cord } \\
\text { elevation }\end{array}$ & - & - & - & - & - & - & - & - & - & - & - \\
\hline $\begin{array}{l}\text { Bed } \\
\text { elevation }\end{array}$ & - & - & - & - & - & - & - & - & - & - & - \\
\hline $\begin{array}{l}\text { Low cord to } \\
\text { bed length }\end{array}$ & - & - & - & - & - & - & - & - & - & - & - \\
\hline
\end{tabular}




\section{APPENDIX E: \\ LEVEL I DATA FORM}


U. S. Geological Survey

Bridge Field Data Collection and Processing Form

Qa/Qc Check by: EW

Date: $7 / 10 / 96$

\section{Structure Number}

HUNTTH00210034 Date: $8 / 2 / 96$ Computerized by: $\mathbf{E W}$ Date: $\underline{\mathbf{7}} \mathbf{1 6 / 9 7}$

\section{A. General Location Descriptive}

1. Data collected by (First Initial, Full last name) M. IVANOFF

2. Highway District Number $\mathbf{0 5}$

County CHITTENDEN (007)

Mile marker $\mathbf{0 0 0 0 0 0}$

Waterway (I - 6) BRUSH BROOK

Route Number TH 21

Town HUNTINGTON (34600)

Road Name SALVAS ROAD

Hydrologic Unit Code: $\mathbf{0 2 0 1 0 0 0 3}$

3. Descriptive comments:

Located 0.01 miles to the junction with town highway 22.

\section{B. Bridge Deck Observations}
4. Surface cover... LBUS 6
RBUS 6
LBDS 6
RBDS 6
Overall 6

(2b us,ds,lb,rb: 1- Urban; 2- Suburban; 3- Row crops; 4- Pasture; 5- Shrub- and brushland; 6- Forest; 7- Wetland)
5. Ambient water surface...US 2
UB 2
DS 2
(1- pool; 2- riffle)

6. Bridge structure type 1 (1- single span; 2- multiple span; 3- single arch; 4- multiple arch; 5- cylindrical culvert; 6- box culvert; or 7- other)
7. Bridge length $\underline{28}$
(feet)
Span length $\mathbf{2 6}$
(feet)
Bridge width 16.1 (feet)

\section{Road approach to bridge:}
8. LB $\underline{1}$ RB 1
( 0 even, 1- lower, 2- higher)
9. LB_2
RB $\underline{2}$
(1-Paved, 2- Not paved)

10. Embankment slope (run / rise in feet / foot)

US left

US right

\begin{tabular}{|c|c|c|c|}
\hline \multicolumn{2}{|c|}{ Protection } & \multirow{2}{*}{ 13.Erosion } & 14.Severity \\
\cline { 6 - 6 } & 12.Cond. & & \\
\hline $\mathbf{0}$ & - & $\mathbf{0}$ & - \\
\hline
\end{tabular}

LBUS

RBUS

RBDS

LBDS

\begin{tabular}{l|l}
\hline 0 & - \\
\hline 2 & 1 \\
\hline 2 & - \\
\hline
\end{tabular}

\begin{tabular}{l|l}
\hline 0 & - \\
\hline 2 & - \\
\hline 1 \\
\hline
\end{tabular}

Bank protection types: 0 - none; 1- $<12$ inches;

2- $<36$ inches; 3- $<48$ inches;

4- < 60 inches; 5- wall / artificial levee

Bank protection conditions: 1- good; 2- slumped;

3- eroded; 4- failed

Erosion: 0 - none; 1- channel erosion; 2 -

road wash; 3- both; 4- other

Erosion Severity: 0 - none; 1- slight; 2- moderate; 3- severe

\section{Channel approach to bridge (BF):}

15. Angle of approach: 0

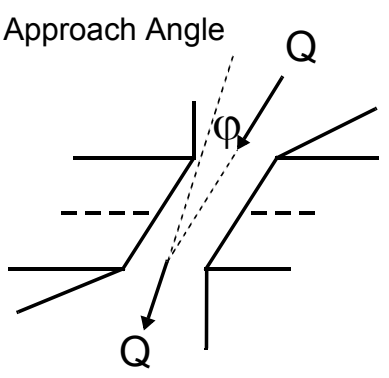

17. Channel impact zone 1 :

Where? LB $(L B, R B)$

Range? 10 feet $\underline{\mathbf{U S}}$

Channel impact zone 2:

Where? _ _ $(L B, R B)$

Range? - $\quad$ feet -

(US, UB, DS) to feet Impact Severity: 0- none to very slight; 1- Slight; 2- Moderate; 3- Severe

16. Bridge skew: 5 Bridge Skew Angle

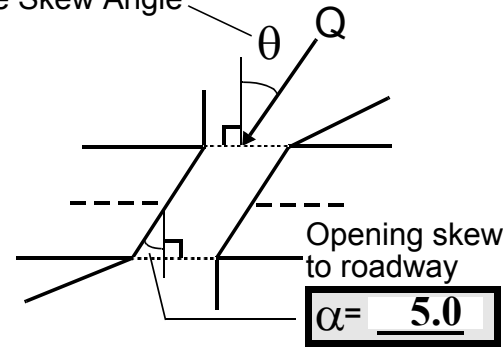

\section{Exist? $\mathbf{Y}(Y$ or $N)$}

Severity $\mathbf{0}$

(US, UB, DS) to $\underline{\mathbf{1 0}}$ feet $\underline{\mathbf{U S}}$

Exist? $\mathbf{N}(Y$ or $N)$

Severity - 
18. Bridge Type: 1a

1a- Vertical abutments with wingwalls

1 b- Vertical abutments without wingwalls

2- Vertical abutments and wingwalls, sloping embankment Wingwalls parallel to abut. face

3- Spill through abutments

4- Sloping embankment, vertical wingwalls and abutments

Wingwall angle less than $90^{\circ}$.

19. Bridge Deck Comments (surface cover variations, measured bridge and span lengths, bridge type variations, approach overflow width, etc.)

\#4: The RBUS is forested with a small pasture near the roadway and a swampy zone with a line of debris near the hill slope.

\#7: Values are from VTAOT, measured values during site visit: bridge length $=30$ feet; bridge span = 26 feet; bridge width $=14$ feet.

\#11: The road approach protection on the RBUS and LBDS is sparse with only a few stones visible. \#18: Only one wingwall exists, the USRWW.

\section{Upstream Channel Assessment}

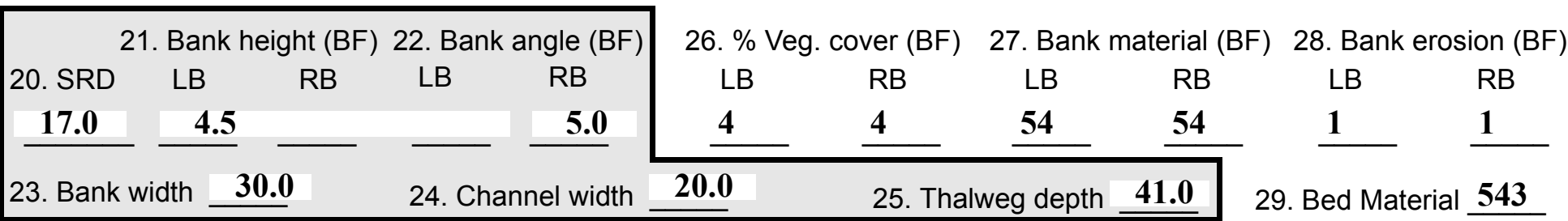

30 .Bank protection type:

LB $\underline{2}$

RB $\underline{2}$

31. Bank protection condition: LB 1

RB 2

SRD - Section ref. dist. to US face \% Vegetation (Veg) cover: 1- 0 to 25\%; 2- 26 to 50\%; 3- 51 to $75 \%$; 4- 76 to $100 \%$

Bed and bank Material: 0- organics; 1- silt / clay, <1/16mm; 2- sand, 1/16 - 2mm; 3- gravel, 2 - 64mm;

4- cobble, 64 - 256mm; 5- boulder, > 256mm; 6- bedrock; 7- manmade

Bank Erosion: 0- not evident; 1- light fluvial; 2- moderate fluvial; 3- heavy fluvial / mass wasting

Bank protection types: 0- absent; 1- < 12 inches; 2- < 36 inches; 3- < 48 inches; 4- < 60 inches; 5- wall / artificial levee

Bank protection conditions: 1-good; 2- slumped; 3- eroded; 4- failed

32. Comments (bank material variation, minor inflows, protection extent, etc.):

\#27: The LB material is boulders and bedrock.

\#29: The bed material consists of boulders, cobble and gravel.

\#30: The LB protection extends 30 feet US from the abutment.

The RB protection extends along the USRWW to 20 feet US. 
33.Point/Side bar present? $\mathbf{N}(Y$ or $N$. if $N$ type ctrl-n pb)34. Mid-bar distance: -

35. Mid-bar width: -

36. Point bar extent: feet (US, UB) to feet (US, UB, DS) positioned $\%$ LB to $\% \mathrm{RB}$

37. Material: -

38. Point or side bar comments (Circle Point or Side; Note additional bars, material variation, status, etc.):

NO POINT BARS

39. Is a cut-bank present? $\underline{\mathbf{Y}}(\mathrm{Y}$ or if $N$ type $c t r-n c b)$

40. Where? $\mathbf{R B}$ (LB or RB)

41. Mid-bank distance: $\mathbf{6 0}$

42. Cut bank extent: 25

feet $\mathbf{U S}$

(US, UB) to $\underline{\mathbf{1 4 0}}$ feet $\underline{\mathrm{US}}$ (US, UB, DS)

43. Bank damage: 1

(1- eroded and/or creep; 2- slip failure; 3- block failure)

44. Cut bank comments (eg. additional cut banks, protection condition, etc.):

\section{Is channel scour present? $\mathbf{N}$ ( $Y$ or if $N$ type ctrl-n cs)}

47. Scour dimensions: Length -

Width -

Depth : -

46. Mid-scour distance: -

48. Scour comments (eg. additional scour areas, local scouring process, etc.):

NO CHANNEL SCOUR

49. Are there major confluences? $\mathbf{N}$

52. Enters on -

Enters on - $\quad(L B$ or $R B)$

Confluence 2: Distance -

54. Confluence comments (eg. confluence name):

NO MAJOR CONFLUENCES

A culvert enters on the LB at 212 feet US. It is two feet in diameter.

\section{Under Bridge Channel Assessment}

55. Channel restraint (BF)? LB 2

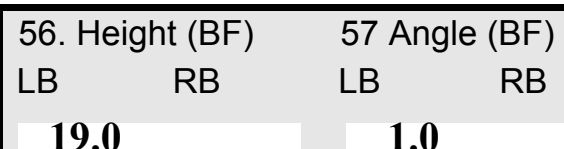

58. Bank width (BF) = (1- natural bank; 2- abutment; 3- artificial levee) ....

\begin{tabular}{lclc} 
61. Material (BF) & \multicolumn{3}{l}{ 62. Erosion (BF) } \\
LB & RB & LB & RB \\
$\mathbf{2}$ & $\mathbf{7}$ & & $\mathbf{7}$ \\
\hline
\end{tabular}

59. Channel width -

60. Thalweg depth $\mathbf{9 0 . 0}$

63. Bed Material -

Bed and bank Material: 0- organics; 1- silt / clay, < 1/16mm; 2- sand, 1/16 - 2mm; 3- gravel, 2 - 64mm; 4- cobble, 64 - 256mm; 5- boulder, > 256mm; 6- bedrock; 7- manmade

Bank Erosion: 0- not evident; 1- light fluvial; 2- moderate fluvial; 3- heavy fluvial / mass wasting

64. Comments (bank material variation, minor inflows, protection extent, etc.):

543

\#63: The bed material consists of boulders, cobbles and gravel. 
65. Debris and Ice Is there debris accumulation?

67. Debris Potential (1- Low; 2- Moderate; 3- High)

69. Is there evidence of ice build-up? 1 (Y or N)

70. Debris and Ice Comments:

1

There are trees along both banks with exposed roots.
$(Y$ or $N)$ 66. Where? $\mathbf{N}$

68. Capture Efficiency 2

(1- Upstream; 2- At bridge; 3- Both)

Ice Blockage Potential $\mathbf{N}$
(1-Low; 2-Moderate; 3- High)

(1-Low; 2-Moderate; 3- High)

\begin{tabular}{|l|c|c|c|c|c|c|c|c|}
\hline Abutments & $\begin{array}{c}71 . \text { Attack } \\
\angle(\mathrm{BF})\end{array}$ & $\begin{array}{c}\text { 72. Slope } \\
\text { (Qmax) }\end{array}$ & $\begin{array}{c}73 \text {. Toe } \\
\text { loc. (BF) }\end{array}$ & $\begin{array}{c}\text { 74. Scour } \\
\text { Condition }\end{array}$ & $\begin{array}{c}\text { 75. Scour } \\
\text { depth }\end{array}$ & $\begin{array}{c}76 . \text { Exposure } \\
\text { depth }\end{array}$ & 77. Material & 78. Length \\
\hline LABUT & & $\mathbf{1 0}$ & $\mathbf{8 6}$ & $\mathbf{2}$ & $\mathbf{2}$ & $\mathbf{0}$ & $\mathbf{3 . 0}$ & $\mathbf{9 0 . 0}$ \\
\hline RABUT & $\mathbf{1}$ & $\mathbf{0}$ & $\mathbf{7 6}$ & & & $\mathbf{2}$ & $\mathbf{2}$ & $\mathbf{2 5 . 5}$ \\
\hline
\end{tabular}

Pushed: $L B$ or RB

Toe Location (Loc.): 0- even, 1- set back, 2- protrudes

Scour cond.: 0- not evident; 1- evident (comment); 2- footing exposed; 3-undermined footing; 4- piling exposed; 5- settled; 6- failed

Materials: 1- Concrete; 2- Stone masonry or drywall; 3- steel or metal; 4- wood

79. Abutment comments (eg. undermined penetration, unusual scour processes, debris, etc.):

0

1.6

1

\#74: In addition to the exposure of the left abutment footing, 0.8 feet of penetration exists three feet from the DS end of the abutment. This penetration void is one foot long (horizontally) and 0.3 feet deep (vertically) with respect to the footing.

80. Wingwalls:

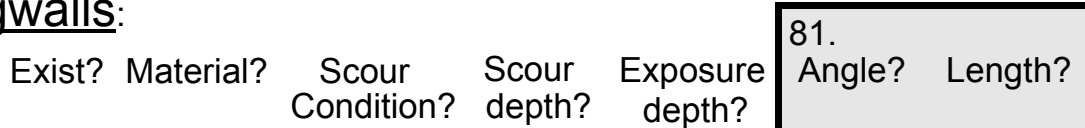

USLWW:

USRWW: $\mathbf{N}$

DSLWW: -

DSRWW: 1

1

$$
\text { Condition? depth? depth? }
$$

\section{Wingwall materials: 1- Concrete; 2- Stone masonry or drywall; 3- steel or metal;} 4- wood

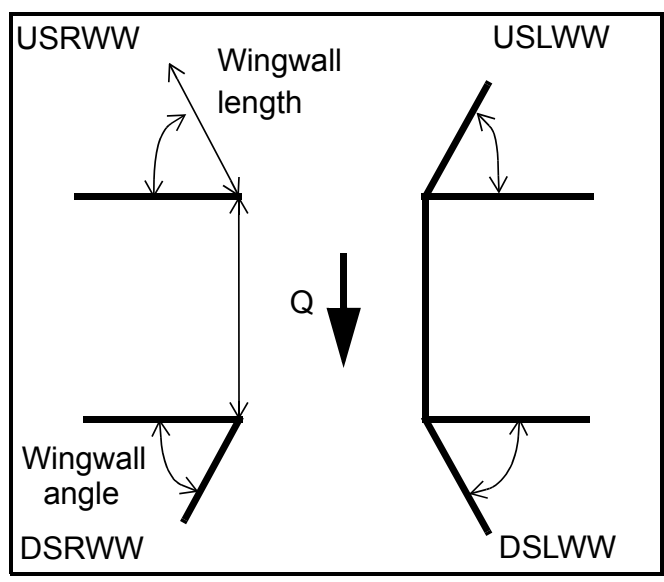

82. Bank / Bridge Protection:

\begin{tabular}{|l|l|l|l|l|l|l|l|c|}
\hline Location & USLWW & USRWW & LABUT & RABUT & LB & RB & DSLWW & DSRWW \\
\hline Type & - & - & $\mathbf{N}$ & - & - & $\mathbf{2}$ & - & $\mathbf{3}$ \\
\hline Condition & $\mathbf{N}$ & - & - & - & - & $\mathbf{1}$ & - & $\mathbf{1}$ \\
\hline Extent & - & - & - & - & $\mathbf{3}$ & $\mathbf{0}$ & $\mathbf{2}$ & - \\
\hline
\end{tabular}

Bank / Bridge protection types: 0- absent; 1- < 12 inches; 2- < 36 inches; 3- < 48 inches; 4- < 60 inches; 
83. Wingwall and protection comments (eg. undermined penetration, unusual scour processes, etc.):

-
-
-
-
-
-
-
-
-
-

\section{Piers:}

84. Are there piers? \#82 (Y or if $N$ type ctrl-n pr)

\begin{tabular}{|l|l|l|l|l|l|l|l|}
\hline \multirow{2}{*}{$\begin{array}{l}85 . \\
\text { Pier no. }\end{array}$} & \multicolumn{3}{|c|}{ width (w) feet } & \multicolumn{3}{c|}{ elevation (e) feet } \\
\cline { 2 - 9 } & w1 & w2 & w3 & e@w1 & e@w2 & e@w3 \\
\hline Pier 1 & - & & & - & $\mathbf{5 5 . 0}$ & $\mathbf{1 0 . 5}$ \\
\hline Pier 2 & - & - & - & - & - & - \\
\hline Pier 3 & - & - & - & - & - & - \\
\hline Pier 4 & - & - & - & - & - & - \\
\hline
\end{tabular}

\begin{tabular}{|l|l|l|l|l|}
\hline Level 1 Pier Descr. & \multicolumn{1}{|c|}{1} & \multicolumn{1}{|c|}{2} & \multicolumn{1}{|c|}{3} & \multicolumn{1}{|c|}{} \\
\hline 86. Location (BF) & $:$ The & with & the DS & - \\
\hline 87. Type & RAB & some & end. & - \\
\hline 88. Material & UT & of & & - \\
\hline 89. Shape & pro- & the & & - \\
\hline 90. Inclined? & tec- & pro- & & - \\
\hline 91. Attack $\angle$ (BF) & tion & tec- & & - \\
\hline 92. Pushed & is & tion & & - \\
\hline 93. Length (feet) & - & - & - & - \\
\hline 94. \# of piles & most & exte & & - \\
\hline 95. Cross-members & ly at & ndin & & - \\
\hline 96. Scour Condition & the & g UB & & - \\
\hline 97. Scour depth & US & and & & - \\
\hline 98. Exposure depth & end & at & N & - \\
\hline
\end{tabular}

LFP, LTB, LB, MCL, MCM, MCR, RB, RTB, RFP

1- Solid pier, 2- column, 3- bent

1-Wood; 2- concrete; 3- metal; 4- stone

1- Round; 2- Square; 3- Pointed

Y-yes; $N$ - no

$L B$ or $R B$

0- none; 1- laterals; 2- diagonals; 3- both

0- not evident; 1- evident (comment);

2- footing exposed; 3- piling exposed;

4- undermined footing; 5- settled; 6- failed 
99. Pier comments (eg. undermined penetration, protection and protection extent, unusual scour processes, etc.):

-
-
-
-
-
-
-
-
-
-

100.

\section{E. Downstream Channel Assessment}

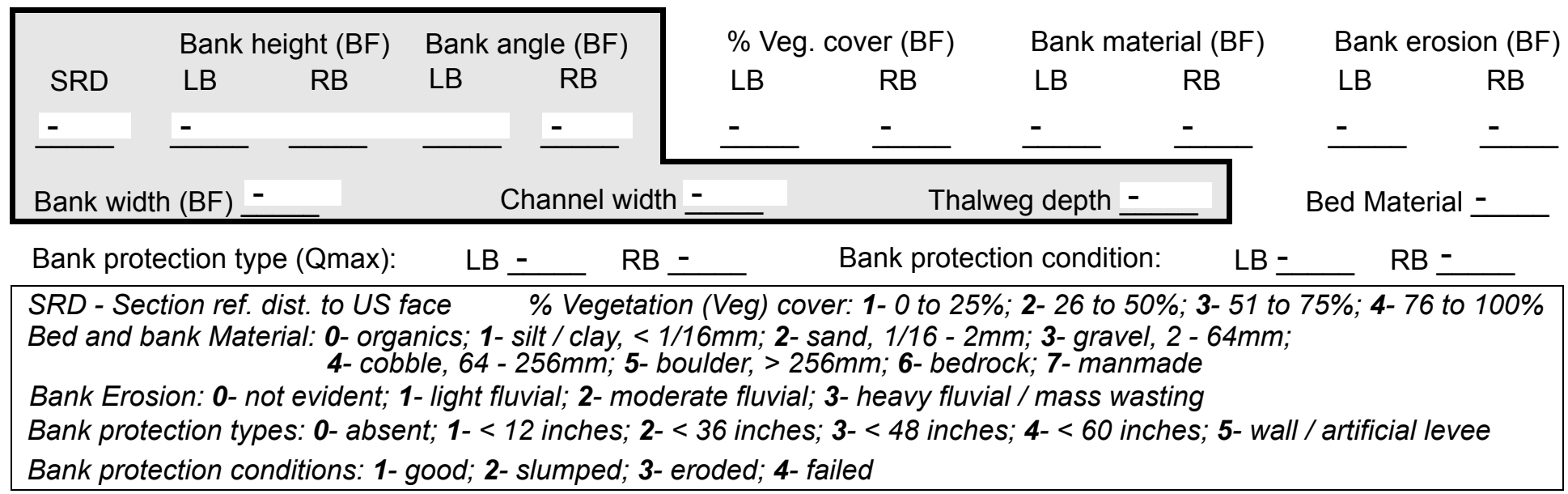

Comments (eg. bank material variation, minor inflows, protection extent, etc.):

-
-
-
-
-
-
-
-
-
-
-
-
-
-
-

101. Is a drop structure present? $\mathbf{N}$ ( $Y$ or $N$, if $N$ type ctrl-n ds) 102. Distance: __ feet 103. Drop: -_ feet 104. Structure material: $\mathbf{O}$ (1- steel sheet pile; 2- wood pile; 3- concrete; 4- other) 105. Drop structure comments (eg. downstream scour depth):

PIERS 
Point bar extent: feet 4 (US, UB, DS) to 4 feet 54 (US, UB, DS) positioned $\mathbf{5 4}$ $\%$ LB to 11 \%RB

Material: 1

Point or side bar comments (Circle Point or Side; note additional bars, material variation, status, etc.):

\section{3}

0

3

$-$

Is a cut-bank present? 1 (Y or if $N$ type ctrl-n $c b)$ Where? The (LB or RB) Mid-bank distance: ban Cut bank extent: $\underline{\mathbf{k}}$ feet $\underline{\mathbf{m a}}$ (US, UB, DS) to teria feet $\underline{\mathbf{l}}$ (US, UB, DS)

Bank damage: con (1-eroded and/or creep; 2- slip failure; 3- block failure)

Cut bank comments (eg. additional cut banks, protection condition, etc.):

sists of boulders and cobbles.

The bed material consists of boulders, cobbles and gravel.

The RB protection consists of large broken concrete blocks and boulders leaning against the end of the

RABUT extending to 6 feet DS and along the left bank of the confluence and right road approach.

Is channel scour present? ___ (Y or if $N$ type ctrl-n cs) Mid-scour distance:

Scour dimensions: Length Width Depth:

Positioned $\%$ LB to $\% \mathrm{RB}$

Scour comments (eg. additional scour areas, local scouring process, etc.):

Are there major confluences? $\mathbf{N}$ ( $Y$ or if $N$ type ctrl-n $m c)$

Confluence 1: Distance NO

Confluence 2: Distance $\underline{\text { STR }}$

Confluence comments (eg. confluence name):

RE

\section{Enters on $\underline{\mathbf{D R}}$ (LB or RB)}

Enters on $\underline{\mathbf{U C}}(L B$ or $R B)$
How many? -

Type $\underline{\mathbf{O P}}$ (1-perennial; 2- ephemeral)

Type TU (1-perennial; 2- ephemeral)

\section{F. Geomorphic Channel Assessment}

107. Stage of reach evolution
1- Constructed

2- Stable

3- Aggraded

4- Degraded

5- Laterally unstable

6- Vertically and laterally unstable 
108. Evolution comments (Channel evolution not considering bridge effects; See HEC-20, Figure 1 for geomorphic descriptors):
Y
43
8
23
DS
60
DS
92
100
32 


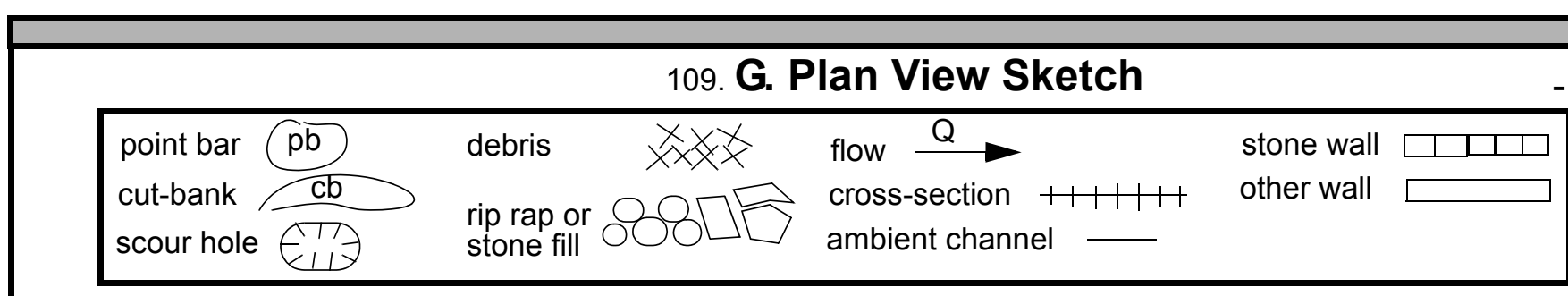

cut-bank $\mathrm{cb}$

scour hole rip rap or
stone fill stone fill cross-section $+1+1+1$ ambient channe other wall 
APPENDIX F:

SCOUR COMPUTATIONS 


\begin{tabular}{|c|c|c|c|}
\hline $\begin{array}{ll}\text { Structure Number: HUNTTH00210034 } \\
\text { Road Number: } & \text { TH } 21\end{array}$ & & $\begin{array}{l}\text { Town : } \\
\text { County: }\end{array}$ & $\begin{array}{l}\text { HUNTINGTON } \\
\text { ADDISON }\end{array}$ \\
\hline Stream: BRUSH BROOK & & & \\
\hline Initials RLB & Checked: & SAO & \\
\hline Analysis of contraction scour, liv & -bed or $\mathrm{c}$ & lear wate & \\
\hline Critical Velocity of Bed Material & converted & to Engl: & sh units) \\
\hline (Richardson and others, 1995, p. 2 & , eq. 16) & & \\
\hline pproach section & & & \\
\hline Characteristic & $100 \mathrm{yr}$ & $500 \mathrm{yr}$ & other $\mathrm{Q}$ \\
\hline Total discharge, cfs & 1700 & 2220 & 1460 \\
\hline Main Channel Area, ft2 & 231 & 244 & 200 \\
\hline Left overbank area, ft2 & 20 & 33 & 6 \\
\hline Right overbank area, ft2 & 9 & 13 & 2 \\
\hline Top width main channel, ft & 41 & 41 & 41 \\
\hline Top width L overbank, ft & 39 & 44 & 9 \\
\hline Top width $\mathrm{R}$ overbank, ft & 11 & 17 & 6 \\
\hline D50 of channel, ft & 0.2953 & 0.2953 & 0.2953 \\
\hline D50 left overbank, ft & -- & -- & -- \\
\hline D50 right overbank, ft & -- & -- & -- \\
\hline $\mathrm{y} 1$, average depth, $\mathrm{MC}$, ft & 5.6 & 6.0 & 4.9 \\
\hline Y1, average depth, LOB, ft & 0.5 & 0.8 & 0.7 \\
\hline $\mathrm{y}^{1}$, average depth, $\mathrm{ROB}, \mathrm{ft}$ & 0.8 & 0.8 & 0.3 \\
\hline Total conveyance, approach & 18060 & 20069 & 13972 \\
\hline Conveyance, main channel & 17563 & 19187 & 13831 \\
\hline Conveyance, LOB & 246 & 528 & 97 \\
\hline Conveyance, ROB & 251 & 354 & 43 \\
\hline Percent discrepancy, conveyance & 0.0000 & 0.0000 & 0.0072 \\
\hline Qm, discharge, MC, cfs & 1653.2 & 2122.4 & 1445.3 \\
\hline Q1, discharge, LOB, Cfs & 23.2 & 58.4 & 10.1 \\
\hline Qr, discharge, ROB, cfs & 23.6 & 39.2 & 4.5 \\
\hline $\mathrm{Vm}$, mean velocity $\mathrm{MC}, \mathrm{ft} / \mathrm{s}$ & 7.2 & 8.7 & 7.2 \\
\hline $\mathrm{Vl}$, mean velocity, LOB, ft/s & 1.2 & 1.8 & 1.7 \\
\hline Vr, mean velocity, ROB, ft/s & 2.6 & 3.0 & 2.2 \\
\hline Vc-m, crit. velocity, MC, ft/s & 10.0 & 10.0 & 9.7 \\
\hline Vc-l, crit. velocity, LOB, ft/s & $\mathrm{ERR}$ & $\mathrm{ERR}$ & ERR \\
\hline Vc-r, crit. velocity, ROB, ft/s & ERR & $\mathrm{ERR}$ & ERR \\
\hline Results & & & \\
\hline Live-bed(1) or Clear-Water(0) Cont & action $\mathrm{ScC}$ & our? & \\
\hline Main Channel & 0 & 0 & 0 \\
\hline Left Overbank & $\mathrm{N} / \mathrm{A}$ & $\mathrm{N} / \mathrm{A}$ & $\mathrm{N} / \mathrm{A}$ \\
\hline Right Overbank & $\mathrm{N} / \mathrm{A}$ & $\mathrm{N} / \mathrm{A}$ & $\mathrm{N} / \mathrm{A}$ \\
\hline
\end{tabular}


Clear Water Contraction Scour in MAIN CHANNEL

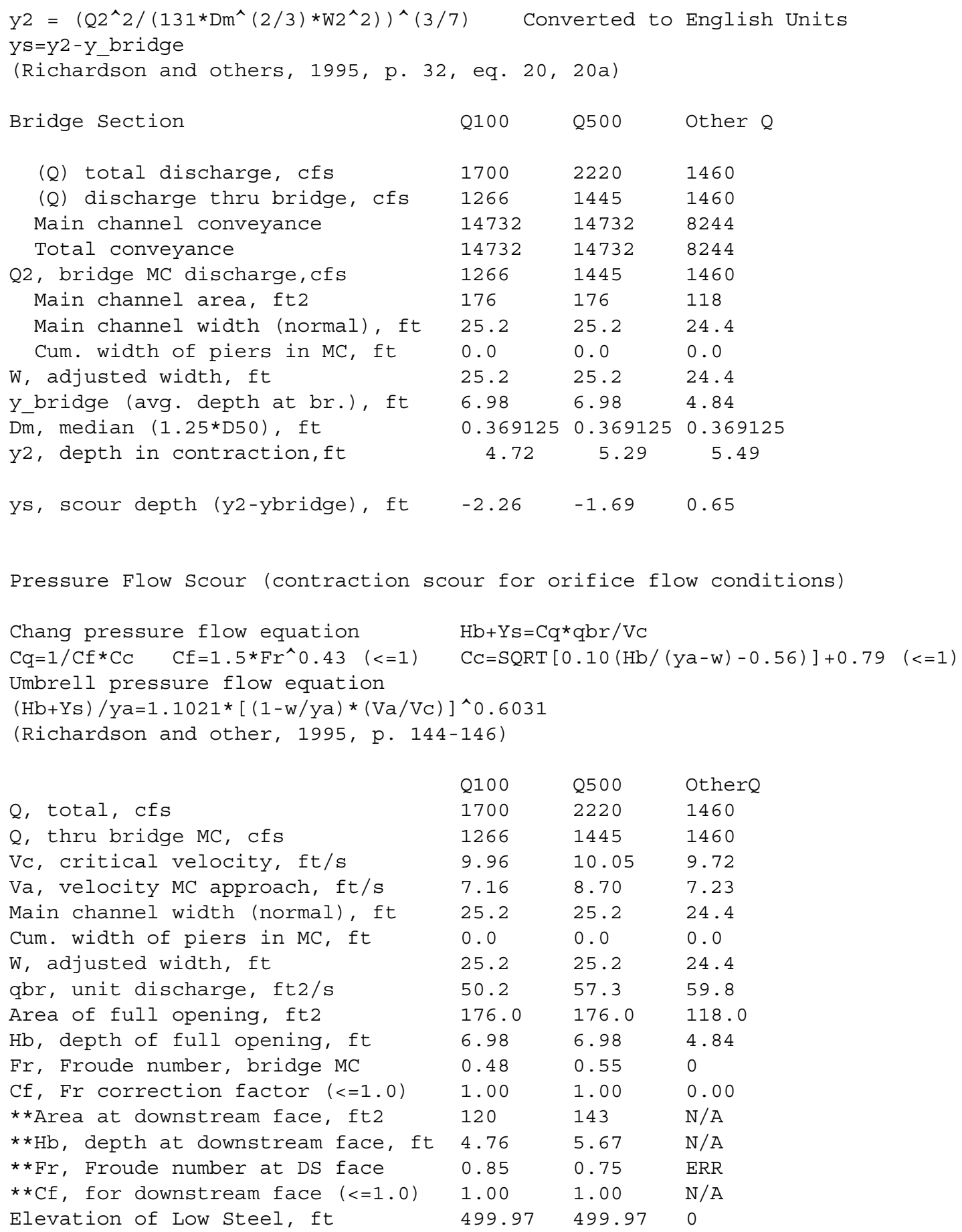




\begin{tabular}{|c|c|c|c|}
\hline Elevation of Bed, ft & 492.99 & 492.99 & -4.84 \\
\hline Elevation of Approach, ft & 501.02 & 501.33 & 0 \\
\hline Friction loss, approach, ft & 0.18 & 0.26 & 0 \\
\hline Elevation of WS immediately US, ft & 500.84 & 501.07 & 0.00 \\
\hline ya, depth immediately US, ft & 7.85 & 8.08 & 4.84 \\
\hline Mean elevation of deck, ft & 503.21 & 503.21 & 0 \\
\hline w, depth of overflow, ft $(>=0)$ & 0.00 & 0.00 & 0.00 \\
\hline Cc, vert contrac correction $(<=1.0)$ & 0.97 & 0.96 & 1.00 \\
\hline$\star *$ Cc, for downstream face $(<=1.0)$ & 0.858039 & 0.90914 & ERR \\
\hline Ys, scour w/Chang equation, ft & -1.79 & -1.07 & $\mathrm{~N} / \mathrm{A}$ \\
\hline Ys, scour w/Umbrell equation, ft & 0.11 & 1.18 & $\mathrm{~N} / \mathrm{A}$ \\
\hline \multicolumn{4}{|c|}{ **=for UNsubmerged orifice flow using estimated downstream bridge face } \\
\hline **Ys, scour w/Chang equation, ft & 1.12 & 0.60 & $\mathrm{~N} / \mathrm{A}$ \\
\hline **Ys, scour w/Umbrell equation, ft & 2.33 & 2.49 & ERR \\
\hline \multicolumn{4}{|c|}{$\begin{array}{l}\text { In UNsubmerged orifice flow, an adjusted scour depth using the Laursen } \\
\text { equation results and the estimated downstream bridge face properties } \\
\text { can also be computed (ys=y2-ybridgeDs) }\end{array}$} \\
\hline y2, from Laursen's equation, ft & 4.72 & 5.29 & 5.49 \\
\hline WSEL at downstream face, ft & 497.72 & 498.66 & -- \\
\hline Depth at downstream face, ft & 4.76 & 5.67 & $\mathrm{~N} / \mathrm{A}$ \\
\hline Ys, depth of scour (Laursen), ft & -0.04 & -0.38 & $\mathrm{~N} / \mathrm{A}$ \\
\hline
\end{tabular}

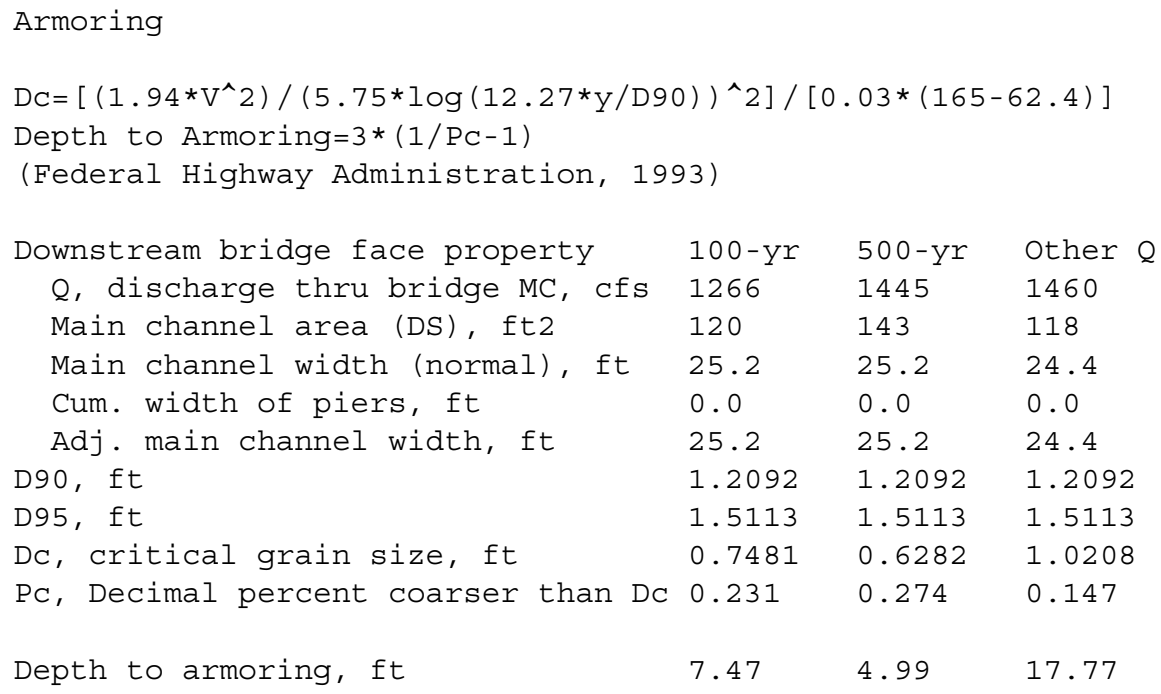




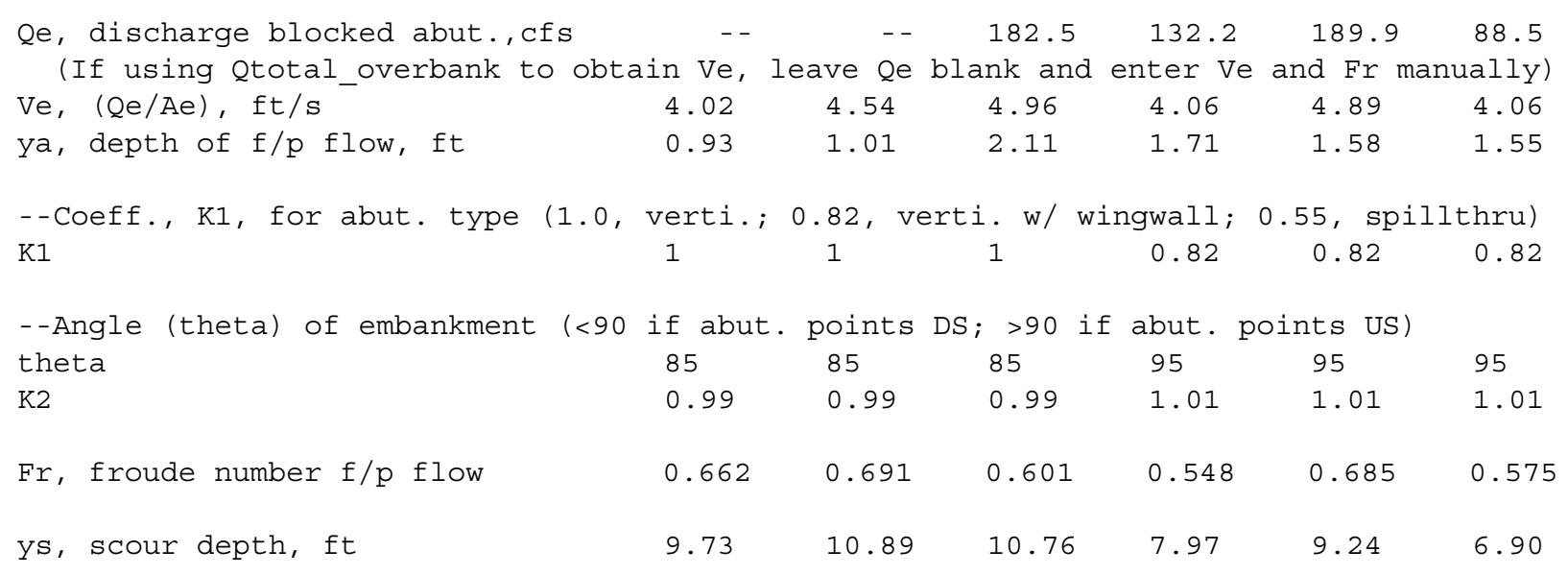

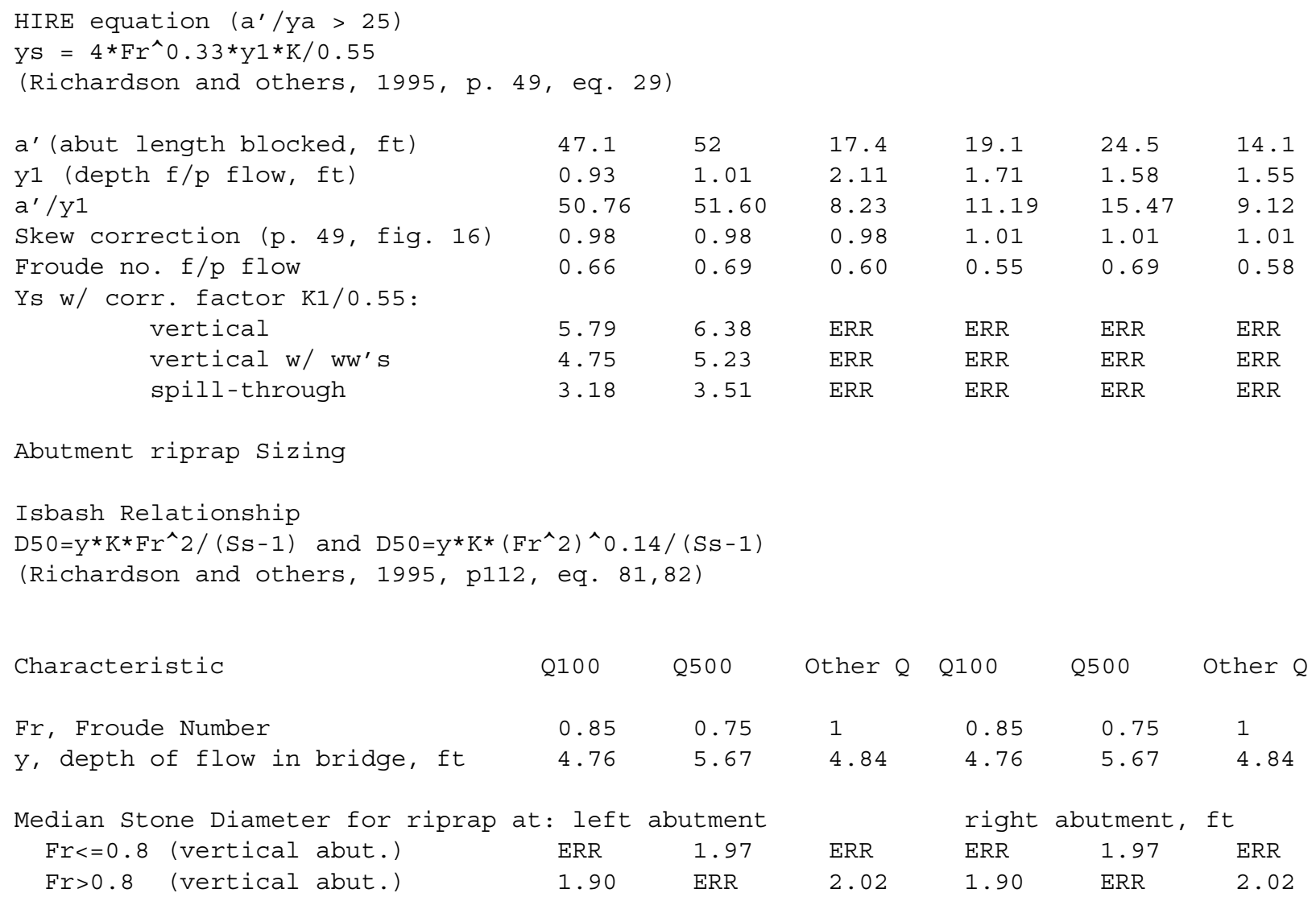


